\title{
Biorefining in the prevailing energy and materials crisis: a review of sustainable pathways for biorefinery value chains and sustainability assessment methodologies
}

Parajuli, Ranjan ; Dalgaard, Tommy; Jørgensen, Uffe; Adamsen, Anders Peter S. ; Knudsen, Marie Trydeman; Birkved, Morten; Gylling, Morten; Schjoerring, Jan Kofod

Published in:

Renewable \& Sustainable Energy Reviews

Link to article, DOI:

10.1016/j.rser.2014.11.041

Publication date:

2015

Document Version

Peer reviewed version

Link back to DTU Orbit

Citation $(A P A)$ :

Parajuli, R., Dalgaard, T., Jørgensen, U., Adamsen, A. P. S., Knudsen, M. T., Birkved, M., Gylling, M., \& Schjoerring, J. K. (2015). Biorefining in the prevailing energy and materials crisis: a review of sustainable pathways for biorefinery value chains and sustainability assessment methodologies. Renewable \& Sustainable Energy Reviews, 43, 244-263. https://doi.org/10.1016/j.rser.2014.11.041

\section{General rights}

Copyright and moral rights for the publications made accessible in the public portal are retained by the authors and/or other copyright owners and it is a condition of accessing publications that users recognise and abide by the legal requirements associated with these rights.

- Users may download and print one copy of any publication from the public portal for the purpose of private study or research.

- You may not further distribute the material or use it for any profit-making activity or commercial gain

- You may freely distribute the URL identifying the publication in the public portal 
Biorefining in the prevailing energy and materials crisis: a review of sustainable pathways for biorefinery value chains and sustainability assessment methodologies

Ranjan Parajuli ${ }^{\mathrm{a},}$, Tommy Dalgaard ${ }^{\mathrm{a}}$, Uffe Jørgensen ${ }^{\mathrm{a}}$, Anders Peter S. Adamsen ${ }^{\mathrm{b}}$, Marie Trydeman Knudsen ${ }^{\mathrm{a}}$, Morten Birkved $^{\mathrm{c}}$, Morten Gylling ${ }^{\mathrm{d}}$, Jan Kofod Schjørring ${ }^{\mathrm{e}}$

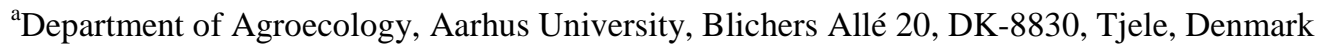

${ }^{\mathrm{b}}$ Department of Engineering, Aarhus University, Hangøvej 2, DK-8200 Aarhus N, Denmark

${ }^{c}$ Department of Manufacturing Engineering and Management, Technical University of Denmark, Building 424, DK2800 Lyngby, Denmark

${ }^{\mathrm{d}}$ Department of Food and Resource Economics, University of Copenhagen, Rolighedsvej 25, DK-1958 Frederiksberg

C, Denmark

${ }^{\text {e}}$ Department of Plant and Environmental Sciences, University of Copenhagen, Thorvaldsensvej 40, DK-1871 Frederiksberg C, Denmark

* Corresponding Author. Email: ranjan.parajuli@agrsci.dk, Phone: +4571606831

\begin{abstract}
:
The aim of the current paper is to discuss the sustainability aspect of biorefinery systems with focus on: biomass supply chains, processing of biomass feedstocks in biorefinery platforms and sustainability assessment methodologies. From the stand point of sustainability, it is important to optimize the agricultural production system and minimize the related environmental impacts at the farming system level. These impacts are primarily related to agri-chemical inputs and the related undesired environmental emissions and to the repercussions from biomass production. At the same time, the biorefineries needs a year-round supply of biomass and about 40-60\% of the total operating cost of a typical biorefinery is related to the feedstocks chosen, and thus highlights on the careful prioritization of feedstocks mainly based on their economic and environmental loadings. Regarding the processing in biorefinery platforms, chemical composition of biomasses is important. Biomasses with higher concentrations of cellulose and hemicelluloses compared to lignin are preferred for bioethanol production in the lignocellulosic biorefinery, since the biodegradability of cellulose is higher than lignin. A green biorefinery platform enables the extraction of protein from grasses, producing an important alternative to importing protein sources for food products and animal feed, while also allowing processing of residues to deliver bioethanol. Currently, there are several approaches to integrate biorefinery platforms, which are aimed to enhance their economic and environmental sustainability. Regarding sustainability assessment, the complexities related to the material flows in a biorefinery and the delivery of alternative biobased products means dealing with multiple indicators in the decision-making process to enable comparisons of alternatives. Life Cycle Assessment is regarded as one of the most relevant tools to assess the environmental hotspots in the biomass supply chains, at processing stages and also to support in the prioritization of any specific biobased products and the alternatives delivered from biorefineries.
\end{abstract}

Keywords: biorefinery, biomass feedstock, sustainability, biobased product, environmental performances, economic performances, Life Cycle Assessment 


\section{Introduction}

The societal need of energy and materials is predicted to reach a crisis point in the near future [1]. This is because of the coupling between escalating demand and cost of fossil fuels upon which the production of chemicals, materials and energy conversions still depend. The high energy intensity in material production has sustainability impacts on the energy sector, environment and economy [2]. Currently fossil fuels contribute about 80\% of the global energy demand, and even if the current political commitments and strategies to tackle the issues of climate change and energy insecurity, as envisioned by different countries are in place, the global energy demand in 2035 is still projected to rise by $40 \%$ with fossil fuels contributing 75\% [3]. The consequences of such dependency of fossil fuels in the agriculture system has resulted hikes in the prices of the raw ingredients for food and feedstuffs [4, 5], since fossil fuel is one of the principal raw material in the modern agriculture [6].

Amid concerns about the sustainability of the energy sector initiatives, the production of biofuel is gaining ground in various economic regions, ranging from developing countries [7] to more developed economies [8]. Currently, there are regulations in Europe on the substitution of non-renewable sources with biofuels for transportation. The European Commission [9] has also focused on biofuels such as bioethanol, biodiesel, biogas, biomethanol, synthetic biofuels, biohydrogen and pure vegetable oil [10] to promote greener transportation fuel. Despite biomass being important source of bioenergy sources issues concerning their environmental impacts, security and stability and diversification of their uses also exist [11-13]. Regarding the debates on biofuels, they are primarily based on the advantages and disadvantages of the classified biofuels, i.e., $1^{\text {st }}$ versus $2^{\text {nd }}$ or $3^{\text {rd }}$ generation fuels. Biofuel production chains based on starch and sugar from corn and sugarcane respectively, and including the liquid fuels derived from animal and vegetable fat using conventional technologies are regarded as $1^{\text {st }}$ generation biofuels [14]. Biofuels based on lignocellulosic feedstock (e.g. straw, grasses, willow) [15] are classified under the $2^{\text {nd }}$ generation types. Algae and advanced processing of the $2^{\text {nd }}$ generation biofuels have been defined as $3^{\text {rd }}$ generation biofuels [16]. The main advantage of the $1^{\text {st }}$ generation biofuel production is primarily the high sugar or oil content in the raw material and the conversion process to energy is relatively easy [17]. Regarding the environmental performances of biofuel production chains, studies including Refs.[18-21] have made the comparisons of the environmental differences of them with the corresponding fossil fuels. For instance, a reduction in the global warming potential (GWP) and increase in fossil fuel savings could be achieved if the most common transportation biofuels (bioethanol and biodiesel) replaces conventional diesel and gasoline. One of the crucial issues related to the $1^{\text {st }}$ generation biofuel production is the belief that it accelerates the competition among the food and feed industries for agricultural land. Furthermore, issues related to indirect landuse changes (iLUC) are also increasingly included in the studies related to sustainable agro-ecological management and aiming to assess the negative impacts on Greenhouse gas (GHG) emissions, biodiversity loss and socio-economic impacts [22]. In this context, a wider range of innovations, including the biorefinery, is now emerging to create new ways of generating bioenergy and explore entirely new types of products in new value chains [23]. Biorefining is regarded as a sustainable processing of a biomass or a combination of different types of biomasses [24] to produce a spectrum of marketable products and energy [17] at a potentially better economic return [24-26]. Nevertheless, it is important to ensure the sustainable supply of biomass without compromising the prevailing land use, soil nutrient loss and the wider environmental and economic sustainability [27, 28]. This demands a comprehensive analysis of biorefinery value chains; covering the entire flows of material inputs and also including the sustainability features of agriculture system upon which production of biorefinery feedstocks are connected.

The current study undertakes a review of fundamental aspects of sustainable biorefining pathways, concentrating on three major areas: (i) introduction to the processes and platforms of biorefinery, potential biobased products markets, 
(ii) discussion of key sustainability parameters, such as relevance of considering potential influences of the input materials (energy and non-energy) at the farming system level and at the stages of biorefining processes, as discussed in sections 2-3, and (iii) outlining possible methodological considerations for the sustainability assessment of biorefining processes, as discussed in section 4. Based on these reviews, the current study also outlines research perspectives in the specific context of Danish agricultural and energy systems, which is discussed in section 5.

\section{Biorefinery processes}

\subsection{Biorefinery platforms}

In the current era, the biorefinery concept is aimed at replacing the 'petroleum refineries' [29] and to reduce the fossil fuel intensity in different production areas [30]. The replacement of fossil-fuel-based products is generally possible if their alternatives (e.g. biochemicals, transportation fuels and fuels for the generation of heat and electricity delivered from biorefineries) [30, 31] are available in the market. According to René and Bert [24], the current biorefinery classification system is in a developing stage, where categories have until now been differentiated based mainly on: (i) raw material inputs (e.g. green biorefinery, whole-crop biorefinery, lignocellulosic biorefinery, marine biorefinery), (ii) type of technology (e.g. biochemical, thermo-chemical biorefinery), (iii) status of technology (conventional and advanced biorefinery, $1^{\text {st }}$ and $2^{\text {nd }}$ generation biorefinery), and (iv) main (intermediate) product produced (syngas platform, sugar platform, lignin platform).

The four main technological processes involved in biorefineries include: thermochemical, biochemical, mechanical/physical and chemical processes [17]. In general biorefinery can also be grouped in two categories: biochemical platform and thermochemical platform. The former type normally focuses on the fermentation of sugars, e.g. extracted from lignocellulosic feedstocks. In this kind of platform after the preparation of feedstocks (e.g. size reduction), the feedstocks are subjected to three basic steps of conversions: (i) conversion of raw biomass to sugar or other fermentation feedstock, (ii) bioconversion of feedstock intermediates using biocatalysts and (iii) processing to deliver added value chemicals, fuel-grade ethanol and other fuels, heat and/or electricity. Likewise, in the case of the thermochemical platform, biorefineries primarily focus on gasification (heating biomass with about one-third of oxygen necessary for complete combustion, producing syngas), and/or pyrolysis (heating biomass in absence of oxygen, producing a pyrolysis oil). The syngas and pyrolysis oil are regarded as cleaner and more efficient fuels than solid biomass. It should be noted that they can also be chemically converted to other valuable fuels and chemicals. In the thermochemical platforms the basic processing steps include: (i) feedstock preparation (drying, size reduction), (ii) conversion of biomass starting with feeding, gasification and/or pyrolysis, and (iii) product delivery with cleaning and conditioning [32]. Currently in order to ensure the environmental and economic sustainability, at several stages of these platforms are integrated.

The lignocellulosic biorefinery type, is generally suited for producing products in an industrial scale, utilizing a variety of raw material (e.g. straw, reed, grass, wood, paper-waste, etc.) and with low prices [33]. Green biorefinery is increasingly becoming popular in several northern European countries. In this type of biorefinery the green biomass is separated into a fiber-rich press cake and a protein-rich press juice [10]. The bulk chemical contents contained in the press cake (e.g. cellulose, starch and dyes) and green juice (e.g. proteins, free amino acids, organic acids, enzymes and minerals) are valuable products in the current market [10, 34]. The green juice is a potential raw material for the production of high quality fodder and cosmetic proteins, human nutrition, chemicals (e.g. lactic acid and lysine), or can alternatively be used as a substrate for biogas production [10]. Another advantage of green biorefinery is its ability to utilize versatile and abundant green biomasses [34]. Further descriptive information of the outlined biorefinery 
classifications can be found in studies including Refs. [10, 24, 35]. Table 1 provides information about different types of biorefinery platforms along with the possible biobased products.

Table 1: Classification of biorefinery types, platforms, feedstocks and processes

\subsection{Potential biorefinery feedstocks and products}

A wider variations on the utilization of bioenergy crops can be found across the world [30]; e.g. corn (maize) is the main crop for the $1^{\text {st }}$ generation bioethanol production in North America, and in Brazil soybean is the main feedstock for biodiesel production and sugarcane for bioethanol production [36]. If the governmental interest to upscale the production capacity of bioethanol, e.g. as currently considered by different developed countries continues, by 2020 its demand could exceed 125 billion liters. The major consequences of such situation are primarily on the feedstock market and on the global capacity of the agricultural system to maintain the bulk biomass demand [37], which pinpoint on the up-scaling of biomass production and the diversification of their uses.

The selection of feedstocks for biorefining is primarily concerned with the issue of sustainable year-round supplies [14, 38, 39]. It is also important to optimize the production costs of biobased products, since generally about 40-60\% of the total operating costs of a typical biorefinery are spent on the feedstock [40]; on a per-gallon basis of ethanol production this equates to $30-32 \%$ of the total production cost [41]. Furthermore, its relevancy is also signified by the chemical compositions of different types of biomass (e.g. Table 2), since these compositions are the basic elements that undergo transformation processes to deliver different valuable products [42]. Galbe et al. [43] made a comparison of biorefinery based on lignocellulosic feedstocks and starch-containing biomasses. They pointed out that the lignocelluloses possess some physical barriers, such as complex structures, presence of various hexose and pentose sugars making the fermentation process complicated, and the presence of lignin or other compounds inhibiting the fermenting organisms. These limitations are further related with a higher energy demand and thus increasing the production costs. However, there have been recent advancements in processing technologies that have more or less addressed such issues; and are discussed in section 2.3. Nonetheless, due to land use and other socio-economic and environmental issues, lignocelluloses are preferable to the starch-containing materials [43].

Table 2: Percentage of dry weight composition of biomass, (based on Ref. [44])

Table 3 shows typical examples of potential biobased feedstocks for biorefining and the alternative fossil fuel-based products available in the current market. For example, succinic acid is a fermentable product derived from glucose and is used in food, chemical and pharmaceutical productions [45, 46]. Likewise, a biochemical such as lactic acid and amino acids are also alternatives to the current raw materials used in food industries. Other commercially available biobased chemicals produced from biorefining include adhesives, cleaning compounds, detergents, dielectric fluids, dyes, hydraulic fluids, inks, lubricants, packaging materials, paints and coatings, paper and box board, plastic fillers, polymers, solvents and sorbents [26].

Table 3: Overview of suitable biorefinery feedstocks with related significant chemical value chains

The global market for the special biochemicals (enzymes, flavors and fragrances, biopesticides, thickening agents, plant growth promoters, essential amino acids, vitamins, etc.) based on biomasses is currently several billion US dollars per year and is growing at a rate of 10-20\% per year [33]. In 2007 a European Commission taskforce [51] produced a report on the estimated potential market for bio-based products in European Union (EU) and also a comprehensive market analysis of public interest in biobased products, such as those based on lignin. In 2005, within the chemical sector the market for bio-based products accounted for about $7 \%$ of the global sales, equivalent to US \$77 billion, and 
the EU industry contributed approximately 30\% to the global sales. By 2020, the value of biobased products is expected to be approximately US $\$ 250$ billion (i.e. $20 \%$ of the chemical industry output will be biobased by that time) [51]. Similarly, the recent study of International Energy Agency (IEA)-Bioenergy (Task 42 Biorefinery) has shown that there is a massive demand of biobased chemicals and has also highlighted on the growing future market [52].

\subsection{Biomass to biobased products and processes involved}

The conversion of a raw biomass into marketable biobased products, such as in a lignocellulosic biorefinery system, occurs in four major steps: (i) pretreatment of the raw biomass, (ii) hydrolysis, (iii) fermentation, and (iv) product recoveries. A detailed description of these key steps can be found in FitzPatrick et al. [53].

In a lignocellulosic biorefinery, pretreatment is necessary to convert the strong lignocellulosic structure into reactive cellulosic intermediates and is a high energy-consuming process [43].The cellulose is structurally strong with a long chains of glucose molecules $\left(\mathrm{C}_{6}\right.$ sugar) linked with $\beta-1,4$ glycosidic linkages, giving a crystalline structure which is difficult to break down (hydrolyze) compared to starch with $\alpha-1,4$ glycosidic linkages [54]. A typical composition of agricultural residues constitute of cellulose 35-50\%, hemicellulose 23-35\% and lignin 14-20\% [30, 44] (Table 2). The compositions of a biomass are significantly changed after undergoing a pretreatment process. For instance, in lignocelluloses the cellulose fraction increases from $43 \%$ to $85 \%$, whereas hemicellulose and lignin reduce from $34 \%$ and $22 \%$ to $6 \%$ and $9 \%$, respectively [55]. Removal of potassium chloride $(\mathrm{KCl})$ is an important part of the pretreatment of straw, as Larsen et al. [56] has reported that about $90 \%$ of the $\mathrm{KCl}$ is found in the liquid fraction of the straw-based biorefinery and can be recovered in the biorefining processes. On a per-gallon basis, the pretreatment represents about 19-22\% of the production cost of bioethanol [41]. The cellulose content of a biomass is hydrolyzed to break down into glucose (by cellulases in the enzymatic treatment, or chemically by sulfuric or other acids). It should be noted that after the pretreatment process, the $\mathrm{C}_{5}$ sugars (mainly pentose, xylose and arabinose) are immediately liberated, and the source of $\mathrm{C}_{6}$ sugars (cellulose) is subjected to hydrolysis. Moreover, under normal conditions, the pretreated biomass should be cooled to a much lower temperature to assist enzymatic hydrolysis in order to liberate $\mathrm{C}_{6}$ sugars, which costs time and money. In the meantime, with the lower temperature there is a high chance of contaminating the fermentation process due to extraneous organisms [57]. It should be noted that the yield of ethanol only from the $\mathrm{C}_{5}$ sugars produced after the fermentation process is normally low [15]. Regarding the case of starch-containing materials, e.g. corn or wheat, liquefaction of the starch fraction is accomplished by adding hydrolytic enzymes ( $\alpha$-amylases) at temperatures of around $90^{\circ} \mathrm{C}$; after this stage the starch molecules are further hydrolyzed by the addition of glucoamylases, producing sugars. In general, sugars are readily fermented by yeast, e.g. Saccharomyces cerevisiae, to produce bioethanol and coproducts like animal feed and fractions of proteins and fiber, which is also referred to as distillers dried grains with solubles (DDGS) [43].

From a techno-economic perspective, all the available pretreatment processes have both advantages and disadvantages. For instance, (i) the lime pretreatment process (though claimed to be the most effective) also requires the input of pressurized oxygen [58], upping the cost, (ii) the organic solvent pretreatment requires additional catalysts and the solvents need to be removed after the use to avoid inhibitory effects on saccharification and fermentation [59], (iii) dilute sulphuric acid pretreatment solubilizes the majority of the hemicellulose and a small amount of lignin, but at higher temperatures it facilitates the production of polysaccharide-degradation products that inhibit the fermentation process [60], (iv) steam pretreatment can be used for different biomasses but requires impregnating agents to improve yields [61], (v) ionic pretreatment, claimed to address the above-mentioned limitations of the other pretreatment 
processes, is relatively costly [41]. Comparative performances of the different types of pretreatment processes can be found in Refs. [62, 63].

Next stage of processing is the hydrolysis of the feedstock. Hydrolysis process is important to yield sugar from both hemicellulose and cellulose, and is one of the critical parameters for ensuring economic viability of the ethanol production [64]. Hydrolysis of biomass can be carried out in two different ways, acid hydrolysis and enzymatic hydrolysis. A dilute acid hydrolysis is generally conducted in two steps (pre-hydrolysis and main hydrolysis) [60]. The limitation of the acid hydrolysis process is a somewhat lower ethanol yield and the need to use resistant materials to avoid corrosion by acid at high temperatures, thereby increasing the production costs. Furthermore, acid neutralization is also necessary to avoid formation of large amounts of gypsum, calcium sulphate and other disposable compounds [43]. The impact of a higher temperature on enzymatic hydrolysis and of a lower temperature on the fermentation process, as discussed above, can be addressed by the use of special fungi as a source of cellulase enzymes [57]. Cellulolytic enzymes [65], generally produced by microorganisms can potentially be used to remove short sugar units from the cellulose chain. The enzymatic process tends to be slower if the biomass is not pretreated before the hydrolysis process and it is also operated under milder processing conditions, but gives relatively higher yields and less toxic products compared to the acid hydrolysis process [43]. The cellulase enzyme is thermophilic by nature, i.e. it can work at temperatures up to $65^{\circ} \mathrm{C}$ (close to pasteurization temperature), thus reduces the cost of lowering the temperature compared to acid hydrolysis process. Most importantly, the ability of this enzyme to work at the higher temperature makes the fermentation process less prone to contamination from extraneous organisms [57]. However, the production cost of the cellulase enzyme is a crucial element, despite the claim that the biotechnology companies Genencor International and Novozymes Biotech have recently developed a technology that can reduce the cellulase cost for the cellulose-to-ethanol process from US\$5.40 per gallon (1 US gallon=3.8 liter) of ethanol to approximately 20 cents per gallon [65]. Pan et al. [66], along a similar line also aired the similar prospect of reducing the cost of manufacturing enzymes by using modern biotechnologies.

Removal of lignin in the initial processing of biomass facilitates enzymatic hydrolysis processes, as a higher concentration of lignin inhibits the process of hydrolysis [67, 68]. An additional advantage of lignin removal is that it represents about $40 \%$ of the heat content in biomass and can thus can be treated as a fuel [68], as have been used in the process of producing cellulose from wood for paper and cardboard [69]. In spite of this, the limitation of lignin is that it is highly contaminated with acid, and therefore hard to utilize even for conversion to energy in a profitable way [31], which definitely has negative consequences in the sustainability of biobased products production [70]. Catalytical processing of biomass is regarded one of the solutions to enable lignin valorization [71] and facilitates the conversion process to produce bulk chemicals. Comprehensive information about catalytic lignin valorization can be found in Ref.[71]. Moreover, conversion of lignin to potential bulk chemicals (e.g. aromatic compounds) [71, 72] instead of burning as fuel, not only displaces fossil-fuel-based chemicals and their related environmental impacts but also adds new value chains in the spectrum of biobased products. Organosolv extraction processes can be used to separate lignin and other useful materials from biomass [73]. In Holladay et al. [74] potential lignin-based products are further listed and described in detail.

The fermentation process is normally performed either in a separate fermenting tank, the process generally being referred to as "separate hydrolysis and fermentation” (SHF), or simultaneously with the hydrolysis of the cellulose chains, also called "simultaneous saccharification and fermentation" (SSF). In the case of fermenting the pentose sugars, the process is also referred to as "simultaneous saccharification and cofermentation" (SSCF)[43]. The relative 
advantages of fermentation along with the hydrolysis processes, with respect to bioethanol production, are discussed in section 3.3.1.

\subsection{Description of material flows in a biorefinery, an example}

A schematic process of "Inbicon” biorefinery model is discussed in this section. The Inbicon biorefinery model was built in 2009 in Denmark as a demonstration plant after several years of research and development at laboratory and pilot scale. The reason for selecting this model are threefold: (i) straw, an agriculture residue, has been one of the principal sources of biomass for bioenergy and a potential source of feedstock for biorefining in Denmark [56], and the biorefinery plant uses this biomass; (ii) the plant uses the enzymatic hydrolysis process (particularly the cellulase enzyme at the current stage), which is arguably attractive as it leads to better yields and with a lower production cost of bioethanol compared to the acid-catalyzed hydrolysis[43]; (iii) the plant is claimed to produce bioethanol, $\mathrm{C}_{5}$ molasses, lignin pellets on a commercial scale [75], which may be of interest to wider research platforms.

Larsen et al. [75] stated that the handling of the biomass in the Inbicon plant is initiated with pre-processing of the biomass residue ((cutting and dry matter (DM) adjustment)) (Figure 1). Condensate containing acetic acid back from the evaporation step is used to adjust the DM content. The pre-processed biomass is hydrothermally treated at different temperatures for different periods of time, which solubilizes the hemicellulose and reorganizes the lignin on the cellulose surface, thus rendering the cellulose more accessible for enzymatic hydrolysis. The pretreated biomass is separated into fibers and liquid streams; the former is subjected to hydrolysis (e.g. enzymatic) after washing and pH adjustment. The hydrolyzed liquefied fibers are pumped from the hydrolysis reactor through a heat exchanger to the fermentation process. In a conventional system, the pretreated biomass usually undergoes the fermentation process in two stages: firstly, the horizontal fermentation where commercial dry yeast is added to convert $\mathrm{C}_{6}$ sugars into bioethanol, whilst $\mathrm{C}_{5}$ sugars (e.g. xylose) are not converted in this stage. In the Inbicon model, after the prehydrolysis, the $\mathrm{C}_{6}$ sugars are fermented in a SSF. Yeast for the fermentation is normally added before the enzymatic hydrolysis is completed and hence the breakdown of cellulose continues along with the fermentation of glucose to ethanol [56]. In the distillation process, the concentration of ethanol is maintained (above 4-6 w/w \%) to reduce the energy requirement in the distillation process [56]. The concentration is maintained by passing it firstly through a rectifying column and then through a molecular sieve [75]. The residual product from the bottom of the distillation column is collected, constituting both solid and liquid particles. The solid particles are dried and pelletized into lignin pellets and used as fuel (e.g. co-firing in a CHP plant to produce heat/electricity). It should be noted that an alternative to the use of lignin as a fuel is its further processing to produce potential bulk chemical derivatives [71, 72, 76, 77], as discussed in section 2.3 .

Figure 1: Illustrative flow of biomass to biovalue products in a biorefinery process, modified after the Ref. [75].

The liquid particles since are enriched with $\mathrm{C}_{5}$ sugars and partly cellulases, and enzymes are recycled for hydrolysis processes. It should be noted that the $\mathrm{C}_{5}$ molasses produced in a biorefinery is suitable for cattle feed, but stabilization of quality for this purpose is crucial [56]. A comparative analysis of $\mathrm{C}_{5}$ molasses with beet and cane molasses was presented by Larsen et al. [75]. The alternative use of $C_{5}$ molasses is as a biogas booster in a manure-based biogas production process. 


\section{Sustainability themes in biorefineries}

3.1. Material inputs in biorefinery pathways: at farm gate level

The choice of feedstock primarily depends on the local climatic and weather conditions, socio-economic issues and national/regional policies that drive the use of available biomasses for specific purposes [78]. Moreover, it is important to assess the socio-economic and environmental performance related to the production of relevant biomass feedstocks and prioritize them based on the minimum environmental impacts and higher economic returns. In the sustainability assessment of an agriculture system, often the material inputs (e.g. fuel and agrichemical, as shown in Table 4-5) are of prime importance. The amount of fertilizer inputs however could not be the only basis to decide upon one type of crop, but it is important while introducing efficient agriculture management practices in order to fulfill the increased biomass demand. For instance, introduction of catch crops (clover/grass, reed canary grass, ryegrass etc.) and their prioritization can be made based on N-fertilizer input, preferably lower, and in such case, based on Table 4 clover/grass could be the best alternatives. It is evident that agri-chemicals inputs are responsible to increase environmental loadings, as suggested in many life cycle impact assessment studies, and are discussed in the following. In the similar prospects, based on the amount of pesticides required for the cultivation of crops, e.g. among maize, sorghum, triticale and miscanthus, as suggested in Blengini et al. [79] maize is the preferable one. Pesticides inputs for cultivating maize, sorghum, triticale and miscanthus are respectively, 0.37, 0.49, 0.37 and $0.43 \mathrm{~kg} / \mathrm{ha} / \mathrm{yr}$.

Table 4: Estimated mineral fertilizer (N, P, K) and lime requirements of selected crops grown in temperate climate zones (kg/ha/yr)

In the same manner, Table 5 shows an example of primary energy consumption for biomass cultivation for annual and perennial crops, based on which miscanthus is preferable among others with high energy output to input ratio. Dalgaard et al. [80] gave comprehensive information on the primary energy input for biomass production and processing, and these inputs are pertinent in a sustainability assessment at the farming system level, e.g. in the assessment of economic and environmental performances of biomass production.

Table 5: Annual energy input in the cultivation and initial processing of biomass in a temperate climate and estimated optimal use of synthetic fertilizers and pesticides in terms of production economy [81]

As coined earlier about the N-fertilizer inputs and their implications to the agro-environment, Heller et al. [82] reported that in the willow cultivation inorganic N-fertilizer application would increase the environmental loadings. About 37\% of the non-renewable energy (NRE) used in willow cultivation is primarily related to N-fertilizer input (mainly manufacturing and application), and they argued that substitution of inorganic N-fertilizer with sewage sludge could increase the net energy ratio of the willow production by more than $40 \%$. Furthermore, the significance of such assessments could be useful to assess the environmental and economic hotspots at the farming system level. These hotspots principally guide to implement the preventive measures to reduce the anticipated impacts.

Parajuli et al. [83], while assessing the environmental performance of miscanthus as a fuel input to a combined heat and power (CHP) plant stated that of the gross NRE used calculated in the conversion of the biomass to $1 \mathrm{MJ}$ of district heat, manufacturing process of agri-chemicals alone covers about $43 \%$. Similarly, of the gross GWP related to conversion of miscanthus to heat and power in the CHP plant, manufacturing process of agri-chemicals covered about 55\%. In the same manner, in another study, Parajuli et al. [83] calculated the consequences of removing 1 ton (t) of straw (with 85\% DM) and stated that the process would lead to a GWP of $-1331 \mathrm{~kg} \mathrm{CO}_{2}$-eq. The calculation also took into account of the emissions from the agri-residue undergoing a decaying process that is avoided because of straw removal from field (otherwise, $143 \mathrm{~kg} \mathrm{CO}_{2}$-eq, if only emission reduction potential related to soil $\mathrm{C}$ buildup is 
considered). For the same quantity of agri-residue, NRE use was reported to be 217 MJ-primary. However, the fact that the straw ashes may be recycled after combustion and was not taken into account at this stage, but was accounted for when assessing the overall consequences in the entire life cycle process of straw utilization [83]. In most of the impact categories, as discussed above, manufacturing of $\mathrm{N}$-fertilizers is the major source of the impact, also in this case (e.g. of the $13 \%$ of the total GWP related to chemical fertilizers, the $\mathrm{N}$-fertilizer alone covers the $8 \%$ ), but it must be noted that there are large differences, dependent on the fertilizer manufacturing technology (typically coal, natural gas, nuclear, or hydropower), and major improvements in these technologies are being implemented over the years [84].

Tsoutsos et al. [85] stated that for the environmental impacts of biodiesel production expressed per unit area, the cultivation of rapeseed had a greater impact than soybean as a raw material, but since the productivity of soy is lower, it requires a larger area to produce the same amount of biodiesel [86]. Also here the use of fertilizers (mainly N) had the greatest environmental impact, followed by pre-processing and transportation of the biomass leading to increase the environmental loads in the biomass conversion processes. Assessment of the net energy and greenhouse gas balances of producing ethanol from corn grain shows inconsistent findings [87-90]. Based on varying corn yields, fertilizer manufacturing efficiencies, corn-to-fuel conversion technologies, fertilizer application rates and evaluation of byproducts and energy inputs, net energy input was found lower than the net energy output of fuel ethanol, as reported by Shapouriet al. and Sarickset al.[87, 88], but Pimentel [89, 90] found the opposite. Kim and Dale [91] claimed that it might not be appropriate to compare biomass feedstocks in terms of cumulative energy and the related GWP, because different agricultural and forestry biomasses have different chemical properties that can be transformed into different valuable products, and if these products are considered as alternatives to fossil fuel-based products they pursue different displacement effects of the environmental impacts.

Another important parameter in the context of N-fertilizer input is nitrogen cycling and losses. A significant rise in the risk of nitrate leaching can take place with increasing amounts of applied $\mathrm{N}$ within a specific cropping system [92]. However, the ploughing period, choice of rotational crops versus perennial crops are among the important factors to impact N-mineralization and seasonal N-uptake, and thereby nitrate leaching can be minimized by manipulating these factors rather than fertilization per se. For instance, after the establishment period, willow and miscanthus showed very low leaching (between 1 and $15 \mathrm{~kg} \mathrm{~N} / \mathrm{ha}$ ) [93]. Nitrate leaching reduction is further linked with a reduction in the emission of nitrous oxide (a GHG), and genereally its emission is claimed to be occuring at the rate of $0.75 \%$ of the leached nitrogen $[94,95]$, and with respect to reduced $\mathrm{N}$-fertiliser inputs it takes place at $1 \%$ of the reduced input [96].

Introduction of catch crops (e.g. rape, oil radish or ryegrass) is regarded to play a vital role to reduce the nitrate leaching occuring with the annual crop production. In Denmark, catch crops are generally sown for up-taking nitrogen during the autumn and winter, and is incorporated into the soil in the spring, and is always followed by a spring sown crop. In the Danish agriculture system there are generally two levels of catch crops based on manure application: (i) if animal manure greater than $80 \mathrm{~kg} \mathrm{~N} / \mathrm{ha}$ are applied, farmers have to establish catch crops in at least 14\% of the 'catch crop base area', and this results in offsetting $25 \mathrm{~kg}$ N/ha from the specific quota of the following crops (ii) if animal manure corresponding to less than $80 \mathrm{~kg} \mathrm{~N} / \mathrm{ha}$ are applied, catch crops should cover at least 10\% of the 'catch crop base area', resulting an offset of $17 \mathrm{~kg} \mathrm{~N} / \mathrm{ha}$ from the specific quota of the following crops [97]. It reveals that in the course of optimizing the agriculture system in order to cope the increased demand of biomass, catch crops play vital role primarily to reduce the undesired emission to the environment. Furthermore, assessment of related environmental impacts of such crops also facilitate to priortize among them as biorefinery feedstocks. 


\subsection{Agricultural management and environmental impacts}

In the context of maximizing the biomass supply to meet the year-round supply to biorefineries, substantial land use change is expected to occur. For instance, changes in the agricultural system may include: land use change (e.g. from annual cropping to forest or grassland), and these processes may lead to changes in GHG-emissions to the atmosphere, and consequences may include also indirect effects on land use elsewhere [98]. Furthermore, the process of carbon (C) accumulation and decay are convertible, and the amount of $\mathrm{C}$ that can be stored in the soil is limited [98]. Significance of such environmental concerns are primarily related in the context of agricultural management practices, where soil $\mathrm{C}$ sequestration and maintenance of soil health are also in high interest, despite the management practice aims to increase crop/biomass yields. Glendining and Powlson [99] discussed that fertilizers (especially N) increase crop yields and returns of organic $\mathrm{C}$ in roots and residues to soil; in the vast majority of situations this leads to a modest increase in soil organic carbon (SOC). In contrast to the argument for the positive changes in SOC resulting from fertilizer application, Johnston et al. and Powlson et al.[98, 100] argued that other GHG's may offset the benefit. They expected that the application of $\mathrm{N}$ fertilizer (( at $144 \mathrm{~kg} \mathrm{~N}^{-1}$ year $^{-1}$ (in addition to P, K, Mg and lime)) would lead to an increased SOC by about $50 \mathrm{~kg} \mathrm{C} \mathrm{ha}^{-1}$ year $^{-1}$, before reaching new equilibrium (generally after 50 years), but commented that it may not be logical to imply that increased fertilization can decrease net GHG-emission, since annual emissions associated with $\mathrm{N}$ fertilizer (including manufacturing and application) is calculated to be four-fold higher than annual SOC increase (5 $\mathrm{kg} \mathrm{CO}_{2}$-equivalent $\mathrm{kg}^{-1} \mathrm{~N}$ ( $200 \mathrm{~kg} \mathrm{C} \mathrm{ha}^{-1}$ vs $50 \mathrm{~kg} \mathrm{C} \mathrm{ha}^{-1}$ respectively ) [98]. This further emphasizes the significance of considering efficient utilization of $\mathrm{N}$ fertilizer [101] in the agricultural system.

Guo and Gifford [102] argued that with the land use change from pasture to plantation, the soil C stocks decline at about $-10 \%$, and from native forest to plantation ( $-13 \%)$, native forest to crop $(-42 \%)$, and pasture to crop land ( $-59 \%)$. Whilst, increment in the soil C stocks with the land use changes follows $+8 \%$ (from native forest to pasture), $+19 \%$ (from crop to pasture), $+18 \%$ (crop to plantation) and from crop to secondary forest is $+53 \%$. The importance of SOC build-up is related to the reducing the emission reduction potential in a life cycle perspective of a farming system. It is thus concluded that increased biomass supply through agricultural intensificaiton should consider the potential changes in the soil health. This is further connected with the rationality of prioritizing biomass feedstocks keeping in mind about: material inputs (energy and non-energy), undesired emisssion (related to agri-chemicals), changes in the soil C pool (in the course of changing the land cover) etc at the farming system level.

\subsection{Inputs and outputs of materials in a biorefinery system-at processing level, an illustration}

We have presented two cases of hydrolysis processes (acid and enzymatic) to discuss on the mass flow that generally take place in a lignocellulosic biorefinery. In the acid hydrolysis process, as argued in Uihlein and Schebek [60], processing of $1 \mathrm{t}$ straw as a feedstock (as input) would lead deliver outputs including ethanol (about $225 \mathrm{~kg}$ ), lignin (300 $\mathrm{kg}$ ), xylite (254 kg), and process heat and electricity production (varying under different scenarios of lignin utilization). Furthermore, for the same input they presented two scenarios of lignin utilization: (i) conversion to process heat (3.2 GJ), and (ii) conversion to electricity (3.46 GJ), and also considering the variation in the rate of acid recovery.

As an example for a biorefinery involving the enzymatic hydrolysis process, we have taken a case of the Inbicon biorefinery plant (see section 2.4 about the plant). Larsen et al. [75] reported that processing of 4 t (86\% DM) of straw per hour would lead to hourly productions of $0.57 \mathrm{t}$ bioethanol, 1.49 t $\mathrm{C}_{5}$ molasses (65\% DM) and $1.74 \mathrm{t}$ lignin pellets (90\% DM). Furthermore, in Inbicon [103] it is reported that the output of ethanol may be further boosted through the use of an advanced yeast technology that facilitates simultaneously consumption of both $\mathrm{C}_{6}$ and $\mathrm{C}_{5}$ sugars and liberate bioethanol. It should be noted that the traditional yeasts normally only consume $\mathrm{C}_{6}$ sugars. The DONG Energy and the 
since the Royal Dutch DSM (the Dutch Life Sciences and Materials Sciences Company) have demonstrated combined fermentation of $\mathrm{C}_{6}$ and $\mathrm{C}_{5}$ sugars from wheat straw on an industrial scale, with the result purportedly giving a $40 \%$ increase in bioethanol yield per ton of straw with the use of advanced yeast [103]. This is expected to lead to a significant drop in the production cost of second-generation bioethanol.

Likewise, Kaparaju et al. [104] analyzed the bioethanol, biohydrogen and biogas products of a wheat-straw-based biorefinery. They calculated the mass flow of the biomass with respect to the amount of sugars and conversions to different products. The pretreated solid particles undergo the hydrolysis-fermentation and distillation processes, finally producing bioethanol from the fermentation broth along with other products. The same study [104] revealed that the total bioethanol production from the input of $0.92 \mathrm{t} \mathrm{DM}$ of straw is about $0.13 \mathrm{t} \mathrm{DM}$. The stillage products (residues obtained from the distillation of the ethanol broth) are also suitable feed material to the biogas digestion process. The pretreated liquid particles (primarily $C_{5}$ sugars) are convertible to bio-hydrogen [105], and effluents from the same liquid stream are also used to produce biogas, similar to stillage [104]. The stillage fraction of the straw input is reported to be 0.29 t DM and effluent is $0.17 \mathrm{t} \mathrm{DM}$ [104]. In this biorefinery framework, it is argued that the use of straw to produce a range of biofuels including biogas is more energetically efficient than producing bioethanol only. It emphasizes that the sustainability of biorefining also needs careful consideration on how waste streams can be capitalized in the entire conversion process.

From the above cases of straw conversion in biorefinery, it is found that production of bioethanol is generally about 1423\% (on mass basis) of the biomass input, and this widens up the necessity to further process lignin and cellulosic content of biomass to other marketable products to ensure a higher return on the investment. In the same context, Uihlein and Schebek [60] argued that conversion of lignin to both heat and electricity was not economically attractive compared to the conversion to acrylic binder. Another case related to the extent of material processing may include the use of $\mathrm{C}_{5}$ molasses as biogas feedstocks or further processed to make them suitable as a feed material for ruminants. These cases open the perspectives of undertaking the performance of biorefinery in relation to the extent of material processing, i.e. whether some of the products should be instantaneously used, or processed further to derive other valuable biobased products, and in the process examine how environmental and socio-economic performances would change.

3.4. Sustainability dimensions of biorefinery value chains with biofuel as an example

3.4.1. Production economics of bioethanol generated with different biorefinery technologies

According to Wright and Brown [106], the production of grain-based bioethanol is relatively more energy-intensive than cellulosic bioethanol. Energy outputs other than biofuels (e.g. process heat, electricity), and distillers' dried grains are claimed to offset the operating costs. If ranked in the order of the lowest capital cost then the order of preferences for the thermochemical conversion of cellulosic biofuels was hydrogen, methanol, and lignocellulosic ethanol and F-T diesel. From this comparison, one may claim that both biochemical and thermo-chemical platforms have opportunities to compete against grain ethanol, if the price of grain were to increase in the market. Furthermore, at the operational level the cost of biomass feedstock covers the major portion of the cost [107, 108]. Lange [4] also argued that the conversion of biomass to biofuels in a biorefinery is significantly influenced by the cost of the feedstock and the technology used. For instance, cost of methyl hydro-oxide (MeOH) or Fischer-Tropsch synthesis and biofuel derived from lignocellulosic biomasses are technology-dominated, whilst the vegetable-oil-based biofuel production is mostly influenced by cost of feedstocks. Furthermore, the production cost is also influenced by the simplicity in the route of feedstock conversion to final product, e.g. feedstocks such as vegetable oil may be expensive (US \$ 13-18/GJ or US \$ 
500-700/t DM), but they are easy to convert, whilst lignocellulose may be cheap (US \$ 2-4/GJ or US \$ 34-70/t DM), but is very difficult to convert $[109,110]$. Similar variations in the production economics can be assumed to occur with the biochemical routes under the similar technological constraints.

Based on the Iogen technology [111], Galbe et al. [43] have shown relative advantages of different biomass conversions (of hardwood, softwood and corn stover) to bioethanol, using different types of hydrolysis and fermentation processes. The maximum raw material handling capacity turned out to be with “consolidated bio-processing” (CBP) (i.e. using an advanced microorganism) and produced 3.1 Mt DM per year of hardwood [43], with a capital cost of 820 Million USD resulting in a net production cost of $\$ 0.2$ per liter of ethanol. The lowest production cost was for enzymatic SSCF at US \$0.13 per liter with hardwood as the feedstock. The production cost of acidic-hydrolyzed bioethanol ranged from US \$0.36-0.53 per liter. For the biofuel production, it is of course important to optimize the cost of raw materials and the feedstock conversion process, as also reported in Refs. [5, 33].

\subsubsection{Environmental performance}

To compare the advantages of biorefineries with petroleum refineries, life cycle impact assessment (LCIA) method has been used in many studies [17, 20, 29]. Most of these studies focused on a single type of feedstock. However, it is of increasing importance to identify and assess the relative advantages of different biorefinery processes, involving different feedstocks and processing technologies. Schaidle et al. [112] discussed on the sustainability assessment of: (i) biochemical production of ethanol from grain and cellulosic biomasses, and (ii) the thermochemical production of F-T diesel from biomass-derived syngas. As Table 6 demonstrates, the environmental performances of a biorefinery (with biofuel as a main product) vary significantly depending on the types of feedstock used. It is claimed that cellulosic ethanol refineries are relatively more sustainable than the grain ethanol and F-T diesel refineries, if greenhouse gas (GHG) emissions is considered as an indicator of the comparison.

Table 6: Life cycle impacts of fuel generated from different types of biorefinery.

The major question in an assessment of the sustainability of biorefinery in today's world is also whether a comparative assessment of biobased products (biofuels, biochemicals and protein) can be carried out. Furthermore, it remains important to assess the land use change impacts, particularly the iLUC effects in relation to changes in the demand for biomass, despite of the claim that even with recovering the protein from the carbohydrate content of forage crops substantial amounts of bioethanol might be produced, and this would result to minimal or no changes in the total occupancy of agricultural land [33]. However, the increased demand of biomass possibly stress that gap in the production volume of cereals in an economy which should be compensated by producing somewhere else through intensification, expansion of agricultural land (linked with deforestation), crop displacement [113] etc.

\section{Methodological concepts for the sustainability assessment of biorefineries}

4.1. Sustainability assessment framework and tools

The complexity associated with biorefinery technologies is primarily related to the multiple material flows, and this has meant dealing with multiple indicators in the decision-making process to compare one product with another. It also highlights the need for an integrated framework of evaluation of alternatives, as also widely experienced in other types of sustainability assessment studies, e.g. in energy planning studies [114]. The sustainability assessment of a biorefinery process can be categorized into mainly three stages: (i) feedstock supply: primarily to determine the suitability and adequacy of potential biomass feedstocks for the transformation process, (ii) biorefinery process performances: to determine the input-output balance of material flows, and (iii) biobased products production: to measure responses to 
overall sustainability aspects (environmental, economic and social) because of the delivery of biobased products from a biorefinery. The latter case is relevant in the cases where there are opportunities of displacing fossil fuel-based products (e.g. petro-chemicals, petroleum products, food/fibers, etc.) by biobased products, and has significant impact on the sustainability of biorefineries. Sammons Jr et al. [115] proposed a general systematic framework for optimizing the product portfolio and process configuration of biorefineries. They have discussed on the economic aspects of delivering biobased products and further encapsulated the optimization framework to enable the decision-making process primarily concerned with whether a certain product should be sold or further processed, or with which processing route to pursue if multiple production pathways exist for a special product.

The typology of sustainability assessment tools [116] can thus in brief be categorized as: monetary, biophysical and indicator tools (Table 7), and the tools can either be applied in an independent or in a combined/integrated manner, depending on the complexity of the production system/services to be assessed.

Table 7: Sustainability assessment tools and possible indicators essential for the assessment

The monetary tools primarily compare the market prices, transfer of benefits, economic modelling of alternatives [116, 127], as well as the aggregation of cost benefits analysis [128], full cost accounting and sustainability assessment modelling [129]. The advantage of such tools in the case of biorefineries is in the assessment of cost optimization opportunities and comparison of different products. The biophysical tools generally consider the dynamics of the material flows [130], estimation of ecological footprints [131], fossil energy balances[80] or exergy and emergy analysis [132, 133] in a production system. In the case of biorefinery, significance of this tool is primarily related to quantify the mass of materials under transformation (e.g. how cellulose, hemicellulose and lignin contents in the biomass are transformed to final products and what are the facilitating material inputs for the process) and in turn correlating their nexus with their socio-economic and environmental paradigms. Similarly, the indicator-based tools primarily involve the process of defining/assigning the composite indicators and evaluation of alternatives via multicriteria assessment [134]. In spite of wider application of indicator-based tool in the sustainability assessment of biorefining processes (primarily to identify the most vulnerable stages of biomass conversions under the broader socioeconomic and environmental categories), the challenges with the use of such tools are (i) the extent and availability of the disaggregated data required for the assessment at different stages of a product value chains, and (ii)possibility of monetizing the environmental indicators along the product value chains. Nevertheless, there have been efforts globally to assess the production volumes of biobased products in a commercial scale and the assessment of the related material inputs for the processing.

Furthermore, Ness et al. [132] broadly classified the sustainability assessment tools as indicator-based assessment, product-related assessment and integrated assessment. The indicator-based assessment was further classified into nonintegrated and integrated indicators. The former basically reflects the comprehensive list of environmental pressure indicators (EPIs) developed by the statistical office of the European Communities (Eurostat) and the indicators developed by the United Nations Commission on Sustainable Development (UNCSD). The EPI indicator sets are being used in economic and social policy-making in European communities covering the issues of resource depletion, waste management, dispersion of toxic substances, air and water pollution, etc. [135]. The UNCSD has put forward 50 core sets of indicators, representing 14 sustainability themes [136]. Prioritizing of such indicators however may require the review of national/regional interests to address the environmental impacts, e.g. environmental impacts may occur at the regional level in the flow of substances (chemical compounds) [137], thus requiring considerations of regional commitments on such issues. 


\subsection{Assessment criteria}

Wang et al. [138] summarized the principles of criteria selection aimed at supporting the decision-making process, primarily for sustainable energy choices. This included the following five major types of principle: (i) the systems principle: reflecting the characteristics and performance of a whole system, (ii) the consistency principle: highlighting the consistency with the research objectives, or product system goals in the decision-making process, (iii) the independency principle:freedom for assessing performances of products/services considering different aspects of alternatives, (iv) the measurability principle: measuring convenience of enumerating the quantitative and qualitative values of the criteria, and (v) the comparability principle: possibility to normalize the criteria and compare among the alternatives. Such principles can also be utilized in the case of a biorefinery to investigate its economic and ecological dimensions, as elaborated in Table 8.

Table 8: Five major principles (elaborated from Wang et al. [138]) in a sustainability assessment of biorefinery processes and examples of the related criteria for decision-making

\subsubsection{Selection and weighting of criteria}

The most common methods to select relevant sustainability assessment criteria, according toWang et al. [138], can be based on the principles of the sustainability assessment as discussed above, and on the 'major' and 'minor' sustainability interests of a political/economic regimes, for instance as detailed in EPI, UNCSD. The Delphi method (devised by a group of experts)[139] is often applied for identifying criteria. Generally, this method assesses the overall rankings of the criteria collected from individuals, and then aggregates them into a single collective framework [140]. Application of the Delphi method in the process of sustainability assessment of a biorefinery process may involve selecting, weighting and evaluating the assessment criteria (and/or setting up the relevant indicators). This approach might be applied starting from the farming system level to prioritize the suitable biomass feedstock and further when deciding the determinant biobased products that can be delivered from a biorefinery. In addition, there are a number of statistical methods that can be applied in the process of selecting sustainability assessment criteria. For instance, the least mean square method, which is primarily relevant when one of the criteria of the assessment does not respond significantly and the performances of alternative criteria turn out to be more important in the evaluation process [138]. Another method, the min-max deviation method [141] can also be applied to weigh the sustainability criteria and respective indicators when looking at the deviation of the values of the assessment criteria. This method has been applied to determine a framework for integrating environmental, economic and technical factors for establishing an ethanol refinery in Canada, as discussed in Ref.[142]. The correlation coefficient of the criteria can also be determined to prioritize the possible best parameters [141]. Furthermore, weighing of sustainability criteria/indicators can be grouped into three categories: (i) subjective weighing, (ii) objective weighing and (iii) combination weighing. Some of the most commonly used tools for the subjective weighing are pair-wise comparison, the least-square method, the Delphi method, the consistent matrix analysis and the analytical hierarchy process (AHP) [143, 144]. This involves the ranking and prioritizing of one indicator against another (or rating of indicators), as also described in Refs.[145, 146]. The objective weighing method uses the measured data and information, thereby assessing their degree of variation [143, 147-149]. Some of the examples of objective weighting methods, as described in Wang et al. [138], are methods for entropy assessment, the technique for order of preference by similarity to ideal solution (TOPSIS) method and the vertical and horizontal method [150], etc. The entropy method primarily shows to what extent the criterion reflects the information of the system and the uncertainties associated with criteria. The vertical and horizontal method is an optimal weighing method, where weighing of a product system can be answered through mathematic models [138]. In 
regard to the sustainability assessment of biorefinery, which necessarily involves comparison among biobased products and between biobased products and fossil-fuel based products, a pair-wise comparison seems effective, as it allows entertaining stakeholder preferences on the qualified sustainability indicators. This aspect is further discussed in section 4.3.2.

\subsection{Integrating sustainability assessment procedures and tools}

\subsubsection{Application of LCA}

LCA can be regarded as an important tool to capture complex features and interdependency of material flows of a production system, process and product. Life Cycle Impact Assessment (LCIA) starts with defining a functional unit, so that environmental performances of any process or production system can be compared with the alternatives. The functional unit determines how the final results should be expressed. It also facilitates to compare the environmental impacts of biomass conversion pathways, e.g. environmental loadings among the cases: firing straw in a CHP plant, gasifying them in a gasification technology, or converting to produce bioethanol. In such cases, the heat content of the biomass could be a basis for defining a functional unit. The complexities with defining the functional unit lie primarily in the necessity to consider 'the main' or 'the co-products', when there are multiple products from a single processing technology. In such case, it is difficult to prioritize the determinant products among the mix of different products; however market analysis of such products helps in the process. There are some cases where more than one functional unit is considered. An example of such is the study for assessing the environmental performances of wood-based biorefinery initiatives (Borregaard, Sarpsborg) [151] in Norway. As reported in Ingunn and Bjørn [151], the terms as such 'main product' or 'co-products' are not used, but all products cellulose, ethanol, lignin (liquid and powder) and vanillin were assessed. They introduced the functional unit as $1 \mathrm{t}$ for cellulose, lignin and vanillin, and $1 \mathrm{~m}^{3}$ for ethanol. Borrion et al. [152] summarized the LCIA studies of lignocellulose biomass based bioethanol production, and have outlined different functional units that can be used for the assessment of the like. It is found that the functional unit primarily depends on the biomass types, such as $\mathrm{m}^{3}$ of hard woodchips (for wood chips based bioethanol production), 1 t ethanol (based on willow), and for wheat based bioethanol production the functional unit were 1 liter of fuel, or simply $1 \mathrm{t}$ straw input. In Cherubini et al. [12] assessment of energy and GHG balances of bioenergy systems based on dedicated energy crops are discussed, and the functional unit for the assessment is based on the land area needed to deliver a specific output. They argued that this approach could connect with the land use issues, particularly if LCIA related to biofuel production have to be carried out. They further suggested that the functional unit of the assessment could be expressed in relation to land use (e.g. $1 \mathrm{~m}^{2}$-year, 1 ha-year, etc.), or to the biomass input (e.g. $\mathrm{t} \mathrm{DM}$ or MJ of biomass) with respect to producible outputs.

Another way of determining a functional unit could be based on the objective of implementing biorefineries in a local and macro-economic setting. In Uihlein and Schebek [60] LCIA is presented for a straw-based biorefinery and is compared with the alternatives in a relatively simplified manner. The assessment was initiated by defining both the reference flow of feedstock and functional unit as $1 \mathrm{t}$ of straw. The environmental performances were assessed with the formulation of an input-output matrix of the reference flow of the feedstock, involving material inputs (e.g. chemicals, fuels) in the input matrix and the final products (e.g. bioethanol, lignin, xylite, process heat and electricity) in the output matrix. In such approach, when normally accountancy of the mass flow is carried out the use of a physical quantity of a biomass feedstock (e.g. $\mathrm{t}$ of straw) can be regarded as a functional unit.

Another important aspect in the LCA of a production system is the debates on the application of either attributional LCA (ALCA) or consequential LCA (CLCA) approaches [153]. Normally, the ALCA approach is used to describe e.g. 
the pollution and resource flows within a chosen system attributed to the delivery of a specified amount of the functional unit $[153,154]$. In contrast, the CLCA estimates how the same pollution and resource flows within a system change in response to a change in output of the functional unit [154, 155]. For example, in the case of a biorefinery it would be relevant to assess the environmental impacts of land use changes due to changes in the demand for biomass (e.g. straw and grasses) compared to their existing use. In this context, importance defining the "main" and "coproducts” may evolve. The reason behind such consideration is that in the case of allocation process, the calculated environmental impacts are allocated for different corresponding products; whilst in the consequential method a system expansion is done, emphasizing that the environmental impacts related to the co-products are substituted with the corresponding average/marginal supplies. Cherubini et al. [156] discussed the categorization of environmental impacts of biorefinery products taking GHG emissions as an impact category. In the assessment, bioethanol was assumed to be the main product and co-products included heat, electricity and phenols. They also presented the annual GHG emissions of a biorefinery, based on either the main products or co-products. They argued that the partitioning could be done through (i) system expansion, (ii) allocation (by mass, energy values and economic values of co-products), and (iii) a hybrid approach. In the case of the system expansion approach, assuming bioethanol as the main product, the coproducts were assigned the function of displacing fossil fuel reference products (e.g. natural gas as the source of fuel to produce heat/electricity was displaced by the co-produced heat/electricity from the biorefinery). Mass allocation in their study showed that the largest contribution to the environmental impact (GHG emissions) was from bioethanol, since the approach only accounted for the products (non-energy) and excluded the energy products (heat and electricity). In the same manner, the energy allocation approach is argued as not being appropriate, since it excludes co-products which do not have any energy value. Cherubini et al. [156] argued that the exergy and economic portioning methods may be more appropriate for covering the effects of both materials and energy flows. Furthermore, the economic allocation method is arguably more rational, especially in a system characterized by a production of high volume but low market-value products (e.g. straw, animal feed and others). In conclusion, the selection and use of a specific allocation method is determined by how the sustainability assessment of the biorefinery process could best fit the designed research question of a particular study [156].

Another important aspect related to the sustainability of a production system is the approach of integrating environmental and economic performances, weighing them and evaluating them. The Life Cycle Cost Analysis (LCCA) method can be used for estimating the life cycle cost of a production system, and is relevant when assessing how best a production system can be optimized [157]. It covers all the relevant costs related to the different stages of conversion of materials (e.g. biomass conversion covering the cultivation, handling, transportation, processing and production of valuable products). This accountancy also helps to compare with the alternative product systems that intend to fulfil the same performance requirements, but differ among themselves with respect to economic costs in a suitable duty cycle.

Furthermore, Bidoki and Wittlinger [158] have argued that the eco-efficiency analysis could integrate the economic and life cycle environmental effects of a production system, providing them with equal weighting. It involves the quantification of sustainability criteria in the entire product life cycle, starting from concept development to design and finally the end-of-life. Combining such sustainability criteria may thus rely on subjective weighing to normalize economic and ecological factors and come up with a value that gives a purposeful comparison. However, as discussed before, there are debates on the validity and transparency required when assigning weights to these criteria, as also discussed in Ref. [159]. The World Council for Sustainable Development has voiced its concern about improving the ecological efficiency while delivering competitively priced goods and services to satisfy the human needs in a qualitative manner [160], and has also brought attention to the concepts of ecological economics to signify the 
introduction of an alternative against other options [161]. Eco-costs are basically the 'virtual cost', employed to measure changes both in the overall economic costs and ecological costs due to recycling/re-use of a product, which is in contrast to the conventional approach where the end-of-life is not monetized in terms of economic and ecological values[117].The eco-cost is thus the sum of the 'marginal prevention costs' of each stage of substitution or prevention of pollution, and also prevention of costs related to material and energy resource depletion [117, 160]. One of the main advantages of the eco-cost method is the garnering of environmental impacts (e.g. assessed with LCA approach) into a single indicator. The single indicator is categorized based on whether the issue dealt with is: (i) a single issue based- e.g. carbon footprint (measured in terms of $\mathrm{CO}_{2}$-eq per unit production but does not cover the cost of material depletion), (ii) damage-based- it aware the producer and consumer to optimize the consumption level and maximize the cleaner productions, but it is complex as it applies subjective weighting principles and is generally based on single indicators, and (iii) prevention-based- it facilitates relatively simplified and transparent calculations and monetizes the results [162]. Furthermore, since the classical way to calculate a 'single indicator' in LCA is to collect the potential emissions in separate groups (e.g. GWP, acidification, eutrophication), the eco-cost determination therefore utilizes a multiplier (a characterization factor, often a marginal prevention cost) to measure the relative significance of environmental categories [162]. These environmental impact categories are summed-up to the level of their 'midpoint' effect, which is generally done by 'normalisation' (e.g. comparison with the pollution in a country or a region) and weighting. Eco-cost determination can be carried out as an extended form of LCA of a biorefinery process. The eco-cost of material depletion can be estimated by assessing the life-cycle impact of material inputs, resource use (resource depletions), savings in fossil fuel consumption, anticipated after the implementation of biorefinery process compared to the alternative biomass conversion technologies and also displacing the corresponding fossil fuel reference products.

\subsubsection{Evaluation Approach}

In sections 2-3 we discussed that in the course of sustainability assessment of biorefining processes, different stages of biomass processing (starting from farming system level to thermochemical and/or biochemical conversions in a biorefinery plant) are to be handled, and these processes have different level of socio-economic and environmental impacts mostly influenced by the material inputs (chemicals, fuel and energy). This implies that the framework of sustainability assessment of biorefining processes constitute of a wide range of indicators. These indicators should be weighed and evaluated and the process might be guided by the principles of the sustainability assessment, e.g. as elaborated in Wang et al. [138] and in Table 8. Dalgaard et al. [163] have also discussed a procedure to evaluate and compare alternatives, e.g. in the case of potential improvements of the different pathways towards a more sustainable economy and have dealt with a number of sustainability indicators. A “traffic light” approach has been proposed: green light categorized as an improvement, yellow as status quo, and red as a negative development compared to the reference situation. The evaluation was made with respect to an extra area unit of specific land-use configurations and technologies, while developing a bioeconomy in rural landscapes.

In the following, we have discussed a simplified approach of quantifying the selected indicators (e.g. as shown in Table 7) and also the process of evaluating them (e.g. Table 9 and equation i). For example, scenarios (' $x$ ', ' $y$ ' and ' $z$ '), as shown in Table 9 can be chosen for the feedstock types or for biorefinery process (types of platforms) or for the biobased products. Let us say that in Scenario-x, a willow crop is evaluated. In the evaluation procedure, initially environmental performance of cultivating the respective feedstocks can be assessed with the use of the LCIA methods, involving environmental impact categories (ranging from 1 to ' $n$ ') (e.g. GWP, NRE use, AP, EP, material extractions.... ' $n$ '). These indicators can be weighted by adopting the suitable weighing methods, as discussed in section 4.2 .1 (say the Delphi Method). Another possibility of identifying the weighting factor is to assess the comparative significance of each 
indicator with respect to as the most critical impacts to the ecosystem, e.g. the EU Environmental Policies focus on GHG emissions, biodiversity and chemical pollution as the most critical factors [164]. For the similar biomass scenarios, as discussed above, economic evaluations can be carried out with the aid of economic indicators (e.g. see Table 7). In the same manner, evaluations for Scenario-y (e.g. straw) and Scenario-z (e.g. a poplar crop) can be carried out. These scenarios are further compared on the basis of calculated environmental and socio-economic burdens. While using the value-based method each parameters of the sustainability assessment (e.g. environmental and socio-economic) are separately weighed and the weighted average of the assessed impact are calculated to derive a sustainability index, which can be used to compare among the alternative scenarios. Whilst in the case of the out-ranking methods a pairwise comparison of alternatives is carried out to assess the preferences of stakeholders on available alternatives. The detail steps of evaluating the alternatives based on the out-ranking methods are discussed in Refs.[165, 166].

Table 9: Schematic matrix of a multi-criteria evaluation process

$$
\text { Evaluation }_{\text {feedstock }(\text { env })}=\frac{\sum_{\text {ind }=1}^{n} \text { quantification }_{\text {indicators }_{\text {ind }} \times \text { Weight }_{\text {indicators }}}}{\sum \text { weight }_{\text {indicators }}}
$$

.equation (i)

In the same manner, depending on the types of feedstocks and the biorefineries, evaluation of alternative biobased product scenarios can be carried out. The alternative scenarios of biobased products may include, e.g. in the case of lignocellulosic biorefinery bioethanol can be regarded as the main products and the co-products as $\mathrm{C}_{5}$ molasses (i.e. protein content) and heat/electricity (e.g. conversion of lignin in a cogeneration unit), whilst in the case of green biorefinery may include extracted protein as the main product and co-product as bioethanol. In the process, LCIA can be used for accounting the environmental impacts related to the conversion of biomass starting from the farming system level to the delivery of biobased products, and economic viability can be assessed using economic tools for the similar route of biomass conversions. Furthermore, integration of both environmental and economic parameters may be necessary to put forward a comparable sustainability index among available alternatives. For such requirements LCC estimates of the entire value chains and assessment of ecological cost, as discussed in section 4.3.1 are the possible methods. The latter case involves the monetization of calculated differences (e.g. eco-cost of reduced material depletions) when an alternative is preferred over other. These complexities in the material processing entail that sustainability assessment of biorefinery system needs to deal with multiple parameters, including socio-economic and environmental impacts.

Multi-criteria decision analysis (MCDA) methods, mainly using value-based methods and outranking- based methods [138] are important in the process of sustainability assessment of biorefinery value chains, since the evaluation can entertain both qualitative and quantitative information in relation to the selected indicators. The former method basically deals with the assigned ratings (or scores) to an alternative, on the way to signify its suitability based on the criteria developed. The range of the rating scale is arbitrary and can be selected to meet the desires of the decision makers. However, once a rating scale is defined, rating values assigned to each of the alternatives for a specific criterion need to be carefully applied so that scores appropriately reflect the differences in the alternatives. The most common value-based MCDA alternative ranking methods are the 'Weighted Average Method' and the 'Discrete Compromise Programming Method'. In the case of outranking method e.g. PROMETHEE method (Preference Ranking Organization Method for Enrichment Evaluations), the ELECTRE methods (Elimination et choice translating reality ), a pair-wise 
comparison of alternatives is performed in order to rank them with respect to a number of criteria [167]. The ELECTRE method mainly considers the preference and ignores the difference level between alternatives when determining the ranking order, whilst the PROMETHEE introduces the preference functions to measure the difference between two alternatives for any criteria [138].

\section{Biorefinery in the context of the Danish agricultural and energy systems}

\section{1. $\quad$ Background for biorefinery setting}

Denmark has made a significant shift to the use of more sustainable energy after the energy crisis of the 1970's [168]. The share of renewable energy on the total primary energy (TPE) production of the country in 2011 had increased almost two-fold compared to year 2000 [169], but 31\% of the renewable energy production was based on imported sources. The use of biodiesel and bioethanol in the country started in respectively 2005 and 2009 [169], and was in coherent with the aim of the Biofuels Directive [170] to promote the use of biofuel in the transport sector. In June 2010, Denmark forwarded its national strategy to the European Commission to fulfill its target of achieving 10\% renewable energy in transport by 2020 [168, 171], and also highlighted that biofuel could make a higher contribution to renewable energy by that time [172, 173]. Furthermore, the country has a long-term sustainable energy goal, which aims to be finally free of fossil fuels by 2050 [174]. In such a transition, Hvelplund et al. [172] reported that the TPE consumption of Denmark by 2050 could be 480 PJ, of which biomass and waste are expected to cover 49\%, and rest by other renewable sources/technologies (wind, photovoltaic, solar thermal and wave energy). Due to the fluctuating nature of wind power, one of the challenges in the future Danish energy mix is to increase the flexibility in power production to improve the balance between supply and demand [175]. Biomass is the most "valuable" resource as a fuel for transport sector in such transitions[172], and one of the challenge in such circumstances is maintaining a sustainable supply for the diversified enduse including the production of heat and power. There is therefore a risk that biomass could be significantly limited in the existing land use pattern of Denmark [176]. However, the recent study on the Danish biomass availability “ The +10 million tonnes study” [177] has highlighted that the biomass supply in Denmark from agriculture and forestry could be increased by up to $10 \mathrm{Mt}$ per annum without substantially affecting the existing food and feed productions.

So far, the most common biomass resources in Denmark include lignocellulose (e.g. wood and straw), waste, manure and a minor proportion from grass, with particular focus on the high-volume types of straw and on wood-based fuels [178]. The average annual production of straw in Denmark was about 3.5 Mt between the period of 2000-2011, of which about $97 \%$ was from cereal crops [178]. In 2010, cereal crops represented 55\% of the agricultural land (i.e. about 2.6 Mha) of the country. Based on the current composition of biomass supplies, if a Danish future energy system is to be based on a higher proportion of biomass, dependency on cereal crops and their residues might be very high. Although thereis good availaility of straw, it is equally necessary to consider a situation where the demand for straw for fuel exceeds its supply. The application sides of Danish recovered straw are $49 \%$ as fuel, $32 \%$ for fodder, and $19 \%$ as bedding materials in livestock houses [177]. This reveals that cases of over-exploitation of biomass (e.g. straw) for energy purposes, or the production of materials could be an issue and has to be taken seriously, if straw-based biorefineries are going to be a fundamental platform of a Danish bioeconomy. The consequences of directing too much of the recovered straw to a single purpose must be diligently examined, for instance impacts on supply of animal feed, soil carbon build-up and related land-use implications in different economies. It may have resulted that because of such concerns in European countries borefineries are gaining attention, not only to deliver energy products, but also to sustainably cope with the increasing demand of high-value proteins. Denmark has an annual net import of $1.6 \mathrm{Mt}$ soybean (average 2006-11) [179], corresponding to 0.8 Mt protein. Totally, Europe has a net import of about 22Mt 
soybean cake (11 Mt protein) and 14.5 Mt soybeans (6 Mt protein) (average 2006-11) [179], mainly from South America. South America (primarily Brazil) is the major supplier for most of European soybean protein import volumes[179]. In the past five decades, every year 2.4 Mha of forest and forest grassland has been replaced by soybean fields in South America. Furthermore, estimates show that in 2020 around 22 Mha of forest and forest grassland in South America could be converted into soy fields, which has significant impact on soil carbon stocks [180]. The high import of soybean is primarily to maintain the livestocks production. However, Europe is not the only region with a high demand for soybean protein, as the import of soybeans to China has also grown by three-fold during the last decade (Figure 2).

Figure 2: Production and export of soybeans from Brazil and gross import of soybean products to Europe and China (Mt DM per year) [179].

Brazil supplies approximately $40 \%$ of the soybean demand of China [179]. Due to the high demand, the soybean production in Brazil has almost doubled during the last decade and the prices have as a result risen three-fold [179], also driven by an increased domestic consumption of soybeans for Brazil's own livestock production (Figure 2). The European and Danish livestock productions are vulnerable to increasing prices of soy protein and combined with the environmental concern related to the production of soybeans, alternative and more sustainable protein sources from e.g. biorefineries are very attractive to the European and Danish livestock sector.

Regarding the biorefinery initiatives in Denmark, Bentsen et al. [181] studied on the energy balance of $2^{\text {nd }}$ generation bioethanol production using Danish winter wheat (considering whole crop). In the study they estimated that with the agricultural production as of 2006 and to meet the 2010 obligation of the biofuel Directive (i.e. 2003/30/EC) fulfilling the $5.75 \%$ of the transportation fuels (gasoline and diesel) about 0.125 Mha of wheat land is required (equivalent to occupying about 5\% of the total Danish agriculture land as of reported in 2010). Other commerical biorefinery facilities in Denmark include (i) Agroferm: utilizes green juices and produces lysins for animal feeds (by fermentation of green juices from green pellet production), (ii) Dangrønt: utilizes grasses to produce green fodder pellets and green juices (green juice is useable asa raw material for the fermentation process [182]), and (iii) Daka biodiesel: utilizes animal fats from slaughterhouses to produce biodiesel, glycerol and potassium sulphate [183]. Currently, a bioethanol plant based on straw and municipal waste is being planned in Måbjerg, West Jutland, which is until now expected to be the largest biorefinery project in the country. Here the Inbicon model is a forerunner for the Måbjerg plant. Furthermore, the BioRefining Alliance, formed with participation from Dong Energy, Novozymes, the Danish Agriculture \& Food Council, Haldor Topsøe, University of Copenhagen, Technical University of Denmark and Aarhus University [184] collectively facilitates the transfer of know-how and the development of biorefineries in Denmark. In addition, BioValue SPIR [185] provides an important platform to develop and accumulate the innovative conversions of biomass to marketable biobased products. The platform is supported financially by the Danish Council for Strategic Research and the Danish Council for Technology and Innovation [185]. The Bio-Value SPIR platform embraces major Danish universities and companies that are joining forces to develop new biomass supply chains and sustainable technological solutions for refining plant material, so that it can be used as a feedstock for production of chemicals, polymers, feed and food ingredients. Specific activities within the Bio-Value SPIR platform are dedicated to assessing the socioeconomic, environmental and ethical aspects of using biomass as a raw material for production of high-value bio-based products. The project "Socioeconomics, sustainability and ethics (SeSE)" under Bio-Value SPIR [185] has also outlined the necessity of linking the research and innovation activities of biorefineries in a more holistic manner, bringing together different production/value chains of biorefineries into a system-wide framework of the sustainability assessment. 


\subsection{Research perspectives}

Consequences of increased demand of biomass in material production could lead to a shortage of feed materials for ruminants and also a depletion of the soil carbon content and nutrient availability [186, 187]. It is thus essential to assess the sustainable quantity of biomass that can be used as feedstocks for biorefineries without exacerbating the aforesaid issues. Furthermore, it is important to identify the possible interactions with the biorefinery products and agricultural inputs - for instance, opportunities to recycle nutrients content in waste water streams of biorefinery to farmers' field, as also suggested by Ahring and Westermann [188] and Langeveld et al. [48]. LCIA of feedstocks supply scenarios are thus relevant to assess: (i) environmental and economic hotspots in the entire biomass supply chains (ii) potential measures to be taken to optimize the production cost and reduce the environmental loadings (iii) potential land use change impacts due to increased demand of biomasses (iv) suitability of a particular feedstock in relation to the prioritized biobased products and so on.

Beyond the farm gate level, at the stages of processing in a biorefinery, economic and environmental performances can be studied in relation to: (i) interaction between the chemical properties of biomass and biobased products, and how they differ among crops with respect to volume and quality of products production, (ii) displacement of corresponding fossil-fuel-based products, and the ecological benefits behind such displacement/substitutions, (iii) utilization of byproducts, e.g. whether lignin based pellets should be burnt to produce heat/power or further processed to produce biochemicals, and the ecological benefits between two pathways. Likewise, it is also relevant to assess the potentiality of recovering the protein from the carbohydrate content of forage crops to reduce the import volume of protein sources. Likewise, sustainability of biorefinery can also carried out considering the variations in the treatment, hydrolysis and fermentation processes, e.g. comparing enzymatic hydrolysis with acid hydrolysis, combined production of ethanol fermenting both $\mathrm{C}_{5}$ and $\mathrm{C}_{6}$ sugars and so on.

Furthermore, while working with the wider scope of biomass conversion through biorefinery platforms, it is also important to review (i) national or regional policies, formulated to enhance the bioeconomy via biorefineries, so that market volume of biobased products can be identified and their underlying economic and environmental performances can be quantified, (ii) whether any incentives are also required to maximize the biomass supply, (iii) the ethics related to such incentives; is it, for example, a good idea to provide incentives to upscale the yield of potential feedstocks for biorefining in the current climate of increasing prices for food and other consumables, and (iv) potential opportunities to increase the yield of biomasses without affecting the market of food and feed. Other important sustainability aspects could be related to social dimensions: technology exposures, willingness to pay by consumers, acceptability, etc., which might be influenced by the marketability of such processes and products. A well-coordinated and integrated framework of a development model is also important to ensure better harmonization between sectors and actors within the platforms of biorefinery value chains. Regarding the willingness to pay, a general belief is that the "European consumer behavior is increasingly affected by these 'green' product qualities, and recent research shows consumers' willingness to pay a premium for more sustainable products” [51]. In spite of this, it might be necessary to educate all the stakeholders and to identify their potential roles and responsibilities in the entire value chain, as also indicated by Dale [33].

\section{Conclusions and way forward}

Biorefinery is increasingly becoming popular to produce spectrum of biobased products with minimum socio-economic and environmental repercussions compared to the 'petroleum refineries'. The important feature of biorefinery is its ability to deliver products that has positive effects while displacing the corresponding fossil-fuel based products and thus the environmental effects related to them. Biorefinery is regarded as a promising emerging technology for 
sustainable biomass value chain development, primarily considering the prospects of: (i) reducing the fossil fuel intensity in the material productions, e.g. conversion of biomass to biofuel and recirculation of produced energy within the biorefinery production system, (ii) optimizing the biomass conversion pathways, e.g. diversified conversion of biomass to a multiple products to ensure better economic and environmental returns, and (iii) enhancing the sustainability of agricultural production system, e.g. minimizing the prevailing issues of food, feed and fuel sectors and a wider land use issue. Moreover, prioritization of a specific biorefineries type/platform may depend on the market demand of biobased products and strategies that a country accustoms to deal its energy and wider socio-economic and environmental issues. The advantage of the green biorefinery is related to the possibility of separating green biomasses into a fiber-rich press cake and a protein rich press juice, while lignocellulosic biorefinery to the capability of delivering products (e.g. bioethanol, $\mathrm{C}_{5}$ molasses and lignin based products) at an industrial scale based on a versatile input of raw materials available at lower prices. Furthermore, in light of maintaining a sustainable and year-round supply of biomass to biorefinery, feedstocks should be thoughtfully prioritized, as they represents about $40-60 \%$ of the total operating cost of a typical biorefinery.

Concerning the sustainability aspects of biorefinery value chains, it is important to judiciously manage the available biomass resources with respect to the demand of different biobased products. It also entails to the risk that a substantial rise in the use of biomass from agriculture, forestry and waste for producing energy or materials would possess negative ecological impacts, socio-economic impacts and additional GHGs emissions. As a part of the sustainability of the agricultural system, prioritization of biomass is thus imperative, so that bulk volume of biomass can be supplied with minimum negative ecological impacts. The significance of such prioritization is also related to reduce the direct and indirect land use change impact while optimizing the agricultural system. Assessment of environmental and socioeconomic performances related to choices of feedstocks is also vital, since different biomasses response differently to the farm inputs and their impacts (e.g. N-fertilizer inputs and related emissions to the environment, changes in the soil $\mathrm{C}$ pools etc.). Likewise, the significance of prioritizing a particular type of biomass or combination of different biomasses is adhered to the sustainability of biorefinery platforms. Composition of cellulose, hemicellulose and lignin in a biomass are important to determine the biorefinery conversion pathways and products to be delivered, as higher the cellulose to lignin ratio, higher is the biodegradability of biomass. In the meantime, the pretreatment process is also important to significantly change the chemical composition of the biomasses (e.g. in lignocelluloses increasing the cellulose fraction from $43 \%$ to $85 \%$, reducing hemicellulose and lignin from $34 \%$ and $22 \%$ to $6 \%$ and $9 \%$, respectively). This process is one of the high energy-consuming processes in biorefining processes. Likewise, the types of hydrolysis process (acid versus enzymatic hydrolysis) is important in the context of maximizing the yield and improving the quality of biobased products and hence their economic viability. For instance the production cost of bioethanol is usually high with the acid hydrolysis compared to enzymatic hydrolysis; the working temperature in the former type is usually high which reduces the fermentation process leading to a lower yield.

Concerning the methodological aspects, Multi-criteria assessment is regarded as a suitable method to assess the overall sustainability of biorefinery processes, as it facilitates the system-wide assessment and evaluation of related physical and socio-economic parameters. These parameters are often assessed with the use of the sustainability assessment tools including, bio-physical (e.g. mass balance), economic (e.g. production cost and benefits) and social (e.g. acceptance, employment opportunities). In the decision making process of the alternatives (e.g. straw versus grasses as feedstocks, fossil fuel-based products versus biobased products, or lignin pellets versus acrylic binder), one has to utilize different types of methods to prioritize, weigh and evaluate the sustainability parameters. In such cases, value-based methods and outranking-based methods are useful tools. These methods are constructed on the basis of scoring process of the 
assessment parameters. Furthermore, in the sustainability assessment process, often decision makers have to involve the preferences of stakeholders on alternatives, which emphasize the use of out-ranking method.

Finally, in the course of sustainability assessment of biorefinery processes it will be necessary to investigate and forward suggestions for: (i) viable innovation of the farming system to maintain sustainable feedstock supply, including increased harvest of biomass without affecting the net production of feed and food and without increasing environmental impacts, (ii) viable innovation in biomass conversion routes (i.e. biochemical versus fuel-oriented) to produce competitive biobased products compared with fossil-fuel-based products.

\section{Acknowledgements}

The article is written as part of a PhD study at the Department of Agroecology, Aarhus University (AU), Denmark. The first author would like to thank the Graduate School of Science and Technology (GSST) of AU for the PhD scholarship. The study is co-funded by the Bio-Value Platform (http://biovalue.dk/), funded under the SPIR initiative by The Danish Council for Strategic Research and The Danish Council for Technology and Innovation, case no: 0603-00522B. Head of section, John E. Hermansen of the same department at AU is also highly acknowledged for providing necessary supports while developing this article. Thanks to Margit Schacht (from Agro Business Park) for providing necessary support in editing this article. We are also grateful to the editor and two anonymous reviewers for their valuable and critical reviews. 
[1] McLaren JS. Crop biotechnology provides an opportunity to develop a sustainable future. Trends in Biotechnology. 2005;23:339-42.

[2] Smil V. ENERGY IN THE TWENTIETH CENTURY: Resources, Conversions, Costs, Uses, and Consequences. Annual Review of Energy and the Environment. 2000;25:21-51.

[3] IEA. Resource to Reserve 2013-Summary. Paris: International Energy Agency; 2013. p. 1-252.

[4] Marris E. Sugar cane and ethanol: Drink the best and drive the rest. Nature. 2006;444:670-2.

[5] Lange JP. Lignocellulose conversion: An introduction to chemistry, process and economics. Biofuels, Bioproducts and Biorefining. 2007;1:39-48.

[6] Pimentel D, Hurd LE, Bellotti AC, Forster MJ, Oka IN, Sholes OD, et al. Food Production and the Energy Crisis. Science. 1973;182:443-9.

[7] Parajuli R, Pokharel GR, Østergaard PA. A comparison of diesel, biodiesel and solar PV-based water pumping systems in the context of rural Nepal. International Journal of Sustainable Energy. 2013:1-18.

[8] Demirbas A. Biofuels sources, biofuel policy, biofuel economy and global biofuel projections. Energy Conversion and Management. 2008;49:2106-16.

[9] COM. An Energy Policy for Europe, Communication from the Commission to the European Council and the European Parliament. Brussel: Commission of the European Communities; 2007. p. 1-27.

[10] Kamm B, Kamm M. Principles of biorefineries. Appl Microbiol Biotechnol. 2004;64:137-45.

[11] Elghali L, Clift R, Sinclair P, Panoutsou C, Bauen A. Developing a sustainability framework for the assessment of bioenergy systems. Energy Policy. 2007;35:6075-83.

[12] Cherubini F, Bird ND, Cowie A, Jungmeier G, Schlamadinger B, Woess-Gallasch S. Energy- and greenhouse gasbased LCA of biofuel and bioenergy systems: Key issues, ranges and recommendations. Resources, Conservation and Recycling. 2009;53:434-47.

[13] Clapp CE, Allmaras RR, Layese MF, Linden DR, Dowdy RH. Soil organic carbon and 13C abundance as related to tillage, crop residue, and nitrogen fertilization under continuous corn management in Minnesota. Soil and Tillage Research. 2000;55:127-42.

[14] Sims REH, Mabee W, Saddler JN, Taylor M. An overview of second generation biofuel technologies. Bioresource Technology. 2010;101:1570-80.

[15] Mosier N, Wyman C, Dale B, Elander R, Lee YY, Holtzapple M, et al. Features of promising technologies for pretreatment of lignocellulosic biomass. Bioresource Technology. 2005;96:673-86.

[16] Gressel J. Transgenics are imperative for biofuel crops. Plant Science. 2008;174:246-63.

[17] Cherubini F. The biorefinery concept: Using biomass instead of oil for producing energy and chemicals. Energy Conversion and Management. 2010;51:1412-21.

[18] Gasol CM, Gabarrell X, Anton A, Rigola M, Carrasco J, Ciria P, et al. Life cycle assessment of a Brassica carinata bioenergy cropping system in southern Europe. Biomass and Bioenergy. 2007;31:543-55.

[19] Quintero JA, Montoya MI, Sánchez OJ, Giraldo OH, Cardona CA. Fuel ethanol production from sugarcane and corn: Comparative analysis for a Colombian case. Energy. 2008;33:385-99.

[20] Kim S, Dale BE. Life cycle assessment of various cropping systems utilized for producing biofuels: Bioethanol and biodiesel. Biomass and Bioenergy. 2005;29:426-39.

[21] Larson ED. A review of life-cycle analysis studies on liquid biofuel systems for the transport sector. Energy for Sustainable Development. 2006;10:109-26.

[22] Van Stappen F, Brose I, Schenkel Y. Direct and indirect land use changes issues in European sustainability initiatives: State-of-the-art, open issues and future developments. Biomass and Bioenergy. 2011;35:4824-34.

[23] Mickwitz P, Hildén M, Seppälä J, Melanen M. Sustainability through system transformation: lessons from Finnish efforts. Journal of Cleaner Production. 2011;19:1779-87.

[24] René vR, Bert A. Status Report Biorefinery 2007. NL-6700 AA Wageningen: Agrotechnology and Food Sciences Group; 2007. p. 1-110. 
[25] Dorado MP, Lin SKC, Koutinas A, Du C, Wang R, Webb C. Cereal-based biorefinery development: Utilisation of wheat milling by-products for the production of succinic acid. Journal of Biotechnology. 2009;143:51-9.

[26] Cherubini F, Jungmeier G, Mandl M, Philips C, Wellisch M, Jørgensen H, et al. IEA bioenergy Task 42 on biorefineries: co-production of fuels, chemicals, power and materials from biomass. IEA Bioenergy Task 42 Countries Report: IEA; 2007. p. 1-37.

[27] Lin Y, Rujiang G, Chong S. Food and energy of the collision alarm. Outlook Weekly. 2006;50:44-5.

[28] Watson HK. Potential to expand sustainable bioenergy from sugarcane in southern Africa. Energy Policy. 2011;39:5746-50.

[29] Cherubini F, Ulgiati S. Crop residues as raw materials for biorefinery systems - A LCA case study. Applied Energy. 2010;87:47-57.

[30] Ghatak HR. Biorefineries from the perspective of sustainability: Feedstocks, products, and processes. Renewable and Sustainable Energy Reviews. 2011;15:4042-52.

[31] Rødsrud G, Lersch M, Sjöde A. History and future of world's most advanced biorefinery in operation. Biomass and Bioenergy. 2012;46:46-59.

[32] Carvalheiro F, Duarte LC, Gírio FM. Hemicellulose biorefineries: a review on biomass pretreatments. Journal of Scientific \& Industrial Research. 2008;6:849-64.

[33] Dale BE. 'Greening' the chemical industry: research and development priorities for biobased industrial products. Journal of Chemical Technology \& Biotechnology. 2003;78:1093-103.

[34] Kromus S, Wachter B, Koschuh W, Mandl M, Krotscheck C, Narodoslawsky M. The green biorefinery Austriadevelopment of an integrated system for green biomass utilization. Chemical and biochemical engineering quarterly. 2004;18:8-12.

[35] Cherubini F, Jungmeier G, Wellisch M, Willke T, Skiadas I, Van Ree R, et al. Toward a common classification approach for biorefinery systems. Biofuels, Bioproducts and Biorefining. 2009;3:534-46.

[36] Hoekman SK. Biofuels in the U.S. - Challenges and Opportunities. Renewable Energy. 2009;34:14-22.

[37] Bohlmann GM. Process economic considerations for production of ethanol from biomass feedstocks. Industrial Biotechnology. 2006;2:14-20.

[38] Stephen JD, Sokhansanj S, Bi X, Sowlati T, Kloeck T, Townley-Smith L, et al. The impact of agricultural residue yield range on the delivered cost to a biorefinery in the Peace River region of Alberta, Canada. Biosystems Engineering. 2010;105:298-305.

[39] Hess JR, Wright CT, Kenney KL. Cellulosic biomass feedstocks and logistics for ethanol production. Biofuels, Bioproducts and Biorefining. 2007;1:181-90.

[40] Caputo AC, Palumbo M, Pelagagge PM, Scacchia F. Economics of biomass energy utilization in combustion and gasification plants: effects of logistic variables. Biomass and Bioenergy. 2005;28:35-51.

[41] Klein-Marcuschamer D, Simmons BA, Blanch HW. Techno-economic analysis of a lignocellulosic ethanol biorefinery with ionic liquid pre-treatment. Biofuels, Bioproducts and Biorefining. 2011;5:562-9.

[42] Galbe M, Zacchi G. Pretreatment of Lignocellulosic Materials for Efficient Bioethanol Production. In: Olsson L, editor. Biofuels: Springer Berlin Heidelberg; 2007. p. 41-65.

[43] Galbe M, Sassner P, Wingren A, Zacchi G. Process Engineering Economics of Bioethanol Production. In: Olsson L, editor. Biofuels: Springer Berlin Heidelberg; 2007. p. 303-27.

[44] Nanda S, Mohammad J, Reddy S, Kozinski J, Dalai A. Pathways of lignocellulosic biomass conversion to renewable fuels. Biomass Conv Bioref. 2013:1-35.

[45] Carole T, Pellegrino J, Paster M. Opportunities in the Industrial Biobased Products Industry. In: Finkelstein M, McMillan J, Davison B, Evans B, editors. Proceedings of the Twenty-Fifth Symposium on Biotechnology for Fuels and Chemicals Held May 4-7, 2003, in Breckenridge, CO: Humana Press; 2004. p. 871-85.

[46] Koutinas AA, Du C, Wang RH, Webb C. Production of Chemicals from Biomass. Introduction to Chemicals from Biomass: John Wiley \& Sons, Ltd; 2008. p. 77-101.

[47] Turley DB. The Chemical Value of Biomass. Introduction to Chemicals from Biomass: John Wiley \& Sons, Ltd; 2008. p. 21-46.

[48] Langeveld JWA, Dixon J, Jaworski JF. Development Perspectives Of The Biobased Economy: A Review. Crop Sci. 2010;50:S-142-S-51. 
[49] Lazerri L, Lorenzo DA. 2009. Green chemistry: An agricultural production chain for biolubricants. Presentation held at the Brainstorming Workshop on green chemistry future and its possible impact on agriculture: The whole farm traceability approach Ispra, Italy.

[50] Somerville CR, Bonetta D. Plants as factories for technical materials. Plant Physiology. 2001;125:168-71.

[51] European Commission. Accelerating the Development of the Market for Bio-based Products in Europe. Report of the European Commission Taskforce on Bio-Based Products: European Commission; 2007. p. 1-24.

[52] IEA. Bio-based Chemicals Value Added Products from Biorefineries. 2011. p. 1-36.

[53] FitzPatrick M, Champagne P, Cunningham MF, Whitney RA. A biorefinery processing perspective: Treatment of lignocellulosic materials for the production of value-added products. Bioresource Technology. 2010;101:8915-22.

[54] Zhang YHP. Reviving the carbohydrate economy via multi-product lignocellulose biorefineries. J Ind Microbiol Biotechnol. 2008;35:367-75.

[55] Alemdar A, Sain M. Isolation and characterization of nanofibers from agricultural residues - Wheat straw and soy hulls. Bioresource Technology. 2008;99:1664-71.

[56] Larsen J, Østergaard Petersen M, Thirup L, Wen Li H, Krogh Iversen F. The IBUS Process - Lignocellulosic Bioethanol Close to a Commercial Reality. Chemical Engineering \& Technology. 2008;31:765-72.

[57] DSM. All you can eat yeast. The Netherlands: DSM, Corporate Communications; 2012. p. 1-3.

[58] Sierra R, Granda C, Holtzapple MT. Short-term lime pretreatment of poplar wood. Biotechnology Progress. 2009;25:323-32.

[59] Zhao X, Cheng K, Liu D. Organosolv pretreatment of lignocellulosic biomass for enzymatic hydrolysis. Appl Microbiol Biotechnol. 2009;82:815-27.

[60] Uihlein A, Schebek L. Environmental impacts of a lignocellulose feedstock biorefinery system: An assessment. Biomass and Bioenergy. 2009;33:793-802.

[61] Eklund R, Galbe M, Zacchi G. The influence of SO2 and H2SO4 impregnation of willow prior to steam pretreatment. Bioresource Technology. 1995;52:225-9.

[62] Kamm B, Kamm M, Schmidt M, Hirth T, Schulze M. Lignocellulose-based Chemical Products and Product Family Trees. Biorefineries-Industrial Processes and Products: Wiley-VCH Verlag GmbH; 2008. p. 97-149.

[63] Talebnia F, Karakashev D, Angelidaki I. Production of bioethanol from wheat straw: An overview on pretreatment, hydrolysis and fermentation. Bioresource Technology. 2010;101:4744-53.

[64] Öhgren K, Bura R, Saddler J, Zacchi G. Effect of hemicellulose and lignin removal on enzymatic hydrolysis of steam pretreated corn stover. Bioresource Technology. 2007;98:2503-10.

[65] Percival Zhang YH, Himmel ME, Mielenz JR. Outlook for cellulase improvement: Screening and selection strategies. Biotechnology Advances. 2006;24:452-81.

[66] Pan X, Arato C, Gilkes N, Gregg D, Mabee W, Pye K, et al. Biorefining of softwoods using ethanol organosolv pulping: Preliminary evaluation of process streams for manufacture of fuel-grade ethanol and co-products. Biotechnology and Bioengineering. 2005;90:473-81.

[67] Chang V, Holtzapple M. Fundamental Factors Affecting Biomass Enzymatic Reactivity. In: Finkelstein M, Davison B, editors. Twenty-First Symposium on Biotechnology for Fuels and Chemicals: Humana Press; 2000. p. 5-37.

[68] Kim TH, Kim JS, Sunwoo C, Lee YY. Pretreatment of corn stover by aqueous ammonia. Bioresource Technology. 2003;90:39-47.

[69] Ragauskas AJ, Williams CK, Davison BH, Britovsek G, Cairney J, Eckert CA, et al. The Path Forward for Biofuels and Biomaterials. Science. 2006;311:484-9.

[70] Rabinovich ML. Wood hydrolysis industry in the soviet union and Russia: A mini-review. Cellulose Chemistry and Technology. 2010;44:173-86.

[71] Zakzeski J, Bruijnincx PC, Jongerius AL, Weckhuysen BM. The catalytic valorization of lignin for the production of renewable chemicals. Chemical Reviews. 2010;110:3552-99.

[72] Haveren Jv, Scott EL, Sanders J. Bulk chemicals from biomass. Biofuels, Bioproducts and Biorefining. 2008;2:4157.

[73] Berlin A, Balakshin MY, Ma R, Maximenko GV, Ortiz D. Organosolv process. In: Ltd. LI, editor.: Google Patents; 2013. 
[74] Holladay J, JF W, JJ B, D J. Top Value-Added Chemicals from Biomass - Volume II-Results of Screening for Potential Candidates from Biorefinery Lignin. Pacific Northwest National Laboratory, Richland, WA: PNNL-16983; 2007. p. 1-79.

[75] Larsen J, Haven MØ, Thirup L. Inbicon makes lignocellulosic ethanol a commercial reality. Biomass and Bioenergy. 2012;46:36-45.

[76] Bozell JJ, Petersen GR. Technology development for the production of biobased products from biorefinery carbohydrates-the US Department of Energy's "Top 10" revisited. Green Chemistry. 2010;12:539-54.

[77] Gallezot P. Conversion of biomass to selected chemical products. Chemical Society Reviews. 2012;41:1538-58.

[78] Dale VH, Kline KL, Wright LL, Perlack RD, Downing M, Graham RL. Interactions among bioenergy feedstock choices, landscape dynamics, and land use. Ecological Applications. 2011;21:1039-54.

[79] Blengini GA, Brizio E, Cibrario M, Genon G. LCA of bioenergy chains in Piedmont (Italy): A case study to support public decision makers towards sustainability. Resources, Conservation and Recycling. 2011;57:36-47.

[80] Dalgaard T, Halberg N, Porter JR. A model for fossil energy use in Danish agriculture used to compare organic and conventional farming. Agriculture, Ecosystems and Environment. 2001;87:51-65.

[81] Uellendahl H, Wang G, Møller H, Jørgensen U, Skiadas IV, Gavala HN, et al. Energy balance and cost-benefit analysis of biogas production from perennial enrgy crops pretreated by wet oxidation. . Water Science \& Technology. 2008;8:1841-7.

[82] Heller MC, Keoleian GA, Volk TA. Life cycle assessment of a willow bioenergy cropping system. Biomass and Bioenergy. 2003;25:147-65.

[83] Parajuli R, Løkke S, Østergaard PA, Knudsen MT, Schmidt JH, Dalgaard T. Life Cycle Assessment of District Heat Production in a Straw fired CHP plant. Biomass and Bioenergy. 2014;68:115-34.

[84] Erisman J, Grinsven H, Leip A, Mosier A, Bleeker A. Nitrogen and biofuels; an overview of the current state of knowledge. Nutr Cycl Agroecosyst. 2010;86:211-23.

[85] Tsoutsos T, Kouloumpis V, Zafiris T, Foteinis S. Life Cycle Assessment for biodiesel production under Greek climate conditions. Journal of Cleaner Production. 2010;18:328-35.

[86] Panoutsou C. Bioenergy in Greece: Policies, diffusion framework and stakeholder interactions. Energy Policy. 2008;36:3674-85.

[87] Shapouri H, Duffield JA, Wang MQ. The Energy Balance of Corn Ethanol: An Update. United States Department of Agriculture, Economic Research Service; 2002.

[88] Saricks C, Santini D, Wang M. Effects of Fuel Ethanol Use on Fuel-Cycle Energy and Greenhouse Gas Emissions. Other Information: PBD: 8 Feb 1999; PBD: 8 Feb 1999; PBD: 8 Feb 19991999. p. Medium: ED; Size: 357 KILOBYTES pages.

[89] Pimentel D. Ethanol fuels: Energy security, economics, and the environment. Journal of Agricultural and Environmental Ethics. 1991;4:1-13.

[90] Pimentel D. The limits of biomass utilization. Encyclopedia of physical science and technology. 2001;3.

[91] Kim S, Dale BE. Cumulative Energy and Global Warming Impact from the Production of Biomass for Biobased Products. Journal of Industrial Ecology. 2003;7:147-62.

[92] Simmelsgaard SE. The effect of crop, N-level, soil type and drainage on nitrate leaching from Danish soil. Soil Use and Management. 1998;14:30-6.

[93] Jørgensen U, Mortensen JV. Kombination af energiafgrødeproduktion og grundvandsbeskyttelse. Kombination af energiafgrødeproduktion og grundvandsbeskyttelse. 2000:97-104.

[94] Jørgensen U, Christensen BT, Olesen JE, Rubæk GH, Petersen BM, Halberg N. Miljø-og naturmæssige konsekvenser af en øget biomasseudnyttelse i Danmark. Copenhagen, Denmark: Ministeriet for Fødevarer, Landbrug og Fiskeri; 2008. p. 129-53.

[95] Olesen JE, Weiske A, Asman WA, Weisbjerg MR, Djurhuus J, Schelde K. FarmGHG. A model for estimating greenhouse gas emissions from livestock farms: Documentation. Danish Institute of Agricultural Sciences; 2004.

[96] IPCC. 2006 IPCC Guidelines for National Greenhouse Gas Inventories. 2006. p. 11.1- .24.

[97] Kristensen IS, Vinther FP. Rules and key values related to fertiliser and animal manure in general and requirements related to extension of the animal production, updated to year 2010/2011. Edited: 25. Jan. 2011 ed. Dept. of Agroecology, Foulum, Aarhus University. 2011. 
[98] Powlson DS, Whitmore AP, Goulding KWT. Soil carbon sequestration to mitigate climate change: a critical reexamination to identify the true and the false. European Journal of Soil Science. 2011;62:42-55.

[99] Glendining M, Powlson D. The effects of long continued applications of inorganic nitrogen fertilizer on soil organic nitrogen: A review. Soil management: Experimental basis for sustainability and environmental quality Adv Soil Sci Ser Lewis Publ, Boca Raton, FL. 1995:385-446.

[100] Johnston AE, Poulton PR, Coleman K. Chapter 1 Soil Organic Matter: Its Importance in Sustainable Agriculture and Carbon Dioxide Fluxes. In: Donald LS, editor. Advances in Agronomy: Academic Press; 2009. p. 1-57.

[101] van der Meer HG. Optimising manure management for GHG outcomes. Australian Journal of Experimental Agriculture. 2008;48:38-45.

[102] Guo LB, Gifford RM. Soil carbon stocks and land use change: a meta analysis. Global Change Biology. 2002;8:345-60.

[103] Inbicon. "DONG Energy and DSM prove cellulosic bio-ethanol fermentation on industrial scale with $40 \%$ higher yield." $\quad$ Retrieved $\quad 01-08, \quad$ from http://www.inbicon.com/About_inbicon/News/Data/Pages/DONGEnergyandDSMprovecellulosicbioethanolfermentationonindustrialscalewith40higheryield.aspx.

[104] Kaparaju P, Serrano M, Thomsen AB, Kongjan P, Angelidaki I. Bioethanol, biohydrogen and biogas production from wheat straw in a biorefinery concept. Bioresource Technology. 2009;100:2562-8.

[105] Lin C-Y, Wu C-C, Hung C-H. Temperature effects on fermentative hydrogen production from xylose using mixed anaerobic cultures. International Journal of Hydrogen Energy. 2008;33:43-50.

[106] Wright MM, Brown RC. Comparative economics of biorefineries based on the biochemical and thermochemical platforms. Biofuels, Bioproducts and Biorefining. 2007;1:49-56.

[107] Hamelinck CN, Hooijdonk Gv, Faaij APC. Ethanol from lignocellulosic biomass: techno-economic performance in short-, middle- and long-term. Biomass and Bioenergy. 2005;28:384-410.

[108] Tijmensen MJA, Faaij APC, Hamelinck CN, van Hardeveld MRM. Exploration of the possibilities for production of Fischer Tropsch liquids and power via biomass gasification. Biomass and Bioenergy. 2002;23:129-52.

[109] Lange JP, Tijm PJA. Processes for converting methane to liquid fuels: Economic screening through energy management. Chemical Engineering Science. 1996;51:2379-87.

[110] Lange J-P. Fuels and Chemicals Manufacturing; Guidelines for Understanding and Minimizing the Production Costs. CATTECH. 2001;5:82-95.

[111] Tolan JS. Iogen's Demonstration Process for Producing Ethanol from Cellulosic Biomass. BiorefineriesIndustrial Processes and Products: Wiley-VCH Verlag GmbH; 2008. p. 193-208.

[112] Schaidle JA, Moline CJ, Savage PE. Biorefinery sustainability assessment. Environmental Progress \& Sustainable Energy. 2011;30:743-53.

[113] Schmidt JH, Brandao M. LCA screening of biofuels-iLUC, biomass manipulation and soil carbon. Copenhagen, Denmark. 2013. p. 3-97.

[114] Løken E. Use of multicriteria decision analysis methods for energy planning problems. Renewable and Sustainable Energy Reviews. 2007;11:1584-95.

[115] Sammons Jr NE, Yuan W, Eden MR, Aksoy B, Cullinan HT. Optimal biorefinery product allocation by combining process and economic modeling. Chemical Engineering Research and Design. 2008;86:800-8.

[116] Gasparatos A, Scolobig A. Choosing the most appropriate sustainability assessment tool. Ecological Economics. 2012;80:1-7.

[117] Vogtländer J, Hendriks P, Brezet P. The EVR model for sustainability - A tool to optimise product design and resolve strategic dilemmas. The Journal of Sustainable Product Design. 2001;1:103-16.

[118] Wiggering H, Rennings K. Sustainability indicators: geology meets economy. Environmental Geology. 1997;32:71-8.

[119] Afgan NH, Carvalho MG. Multi-criteria assessment of new and renewable energy power plants. Energy. 2002;27:739-55.

[120] Chatzimouratidis AI, Pilavachi PA. Technological, economic and sustainability evaluation of power plants using the Analytic Hierarchy Process. Energy Policy. 2009;37:778-87. 
[121] Schmidt JH. Development of LCIA characterisation factors for land use impacts on biodiversity. Journal of Cleaner Production. 2008;16:1929-42.

[122] Weidema B P, Ekvall T, R H. Guidelines for application of deepened and broadened LCA. International Journal of Life Cycle Assessment: Co-ordination Action for innovation in Life-Cycle Analysis for Sustainability (Calcas); 2009. p. 1-49.

[123] Whitmore AP, Schröder JJ. Intercropping reduces nitrate leaching from under field crops without loss of yield: A modelling study. European Journal of Agronomy. 2007;27:81-8.

[124] Akash BA, Mamlook R, Mohsen MS. Multi-criteria selection of electric power plants using analytical hierarchy process. Electric Power Systems Research. 1999;52:29-35.

[125] Mamlook R, Akash BA, Mohsen MS. A neuro-fuzzy program approach for evaluating electric power generation systems. Energy. 2001;26:619-32.

[126] Renn O. Social assessment of waste energy utilization scenarios. Energy. 2003;28:1345-57.

[127] Srinivasan RS, Braham WW, Campbell DE, Curcija DC. 2011. Sustainability assessment frameworks, evaluation tools and metrics for buildingsand its environment- A review. 12th Conference of International Building Performance Simulation Association, 14-16 November. , Sydney.

[128] Hanley N, Spash CL. Cost-benefit analysis and the environment: Edward Elgar Cheltenham; 1993.

[129] Bebbington J, Brown J, Frame B. Accounting technologies and sustainability assessment models. Ecological Economics. 2007;61:224-36.

[130] Haberl H, Fischer-Kowalski M, Krausmann F, Weisz H, Winiwarter V. Progress towards sustainability? What the conceptual framework of material and energy flow accounting (MEFA) can offer. Land Use Policy. 2004;21:199-213.

[131] Kitzes J, Galli A, Bagliani M, Barrett J, Dige G, Ede S, et al. A research agenda for improving national Ecological Footprint accounts. Ecological Economics. 2009;68:1991-2007.

[132] Ness B, Urbel-Piirsalu E, Anderberg S, Olsson L. Categorising tools for sustainability assessment. Ecological Economics. 2007;60:498-508.

[133] Hepbasli A. A key review on exergetic analysis and assessment of renewable energy resources for a sustainable future. Renewable and Sustainable Energy Reviews. 2008;12:593-661.

[134] Cherchye L, Moesen W, Rogge N, Van Puyenbroeck T, Saisana M, Saltelli A, et al. Creating composite indicators with DEA and robustness analysis: the case of the Technology Achievement Index. J Oper Res Soc. 2007;59:239-51.

[135] European Communities. Eurostat-Environmental pressure indicators for the EU. Luxembourg: Office for Official Publications of the European Communities: European Communities; 2001. p. 1-161.

[136] UN. Indicators for sustainable development: Guidelines and methodologies. 3 ed. United Nations, New York: United Nations,; 2007. p. 1-93.

[137] Lindqvist A, Von Malmborg F. What can we learn from local substance flow analyses? The review of cadmium flows in Swedish municipalities. Journal of Cleaner Production. 2004;12:909-18.

[138] Wang J-J, Jing Y-Y, Zhang C-F, Zhao J-H. Review on multi-criteria decision analysis aid in sustainable energy decision-making. Renewable and Sustainable Energy Reviews. 2009;13:2263-78.

[139] Andersen PS, Vejre H, Dalgaard T, Brandt J. An indicator-based method for quantifying farm multifunctionality. Ecological Indicators. 2013;25:166-79.

[140] Handfield R, Walton SV, Sroufe R, Melnyk SA. Applying environmental criteria to supplier assessment: A study in the application of the Analytical Hierarchy Process. European Journal of Operational Research. 2002;141:70-87.

[141] Yaghoobi MA, Tamiz M. A method for solving fuzzy goal programming problems based on MINMAX approach. European Journal of Operational Research. 2007;177:1580-90.

[142] Luk J, Fernandes H, Kumar A. A conceptual framework for siting biorefineries in the Canadian Prairies. Biofuels, Bioproducts and Biorefining. 2010;4:408-22.

[143] Wang JJ, Jing YY, Zhang CF, Shi GH, Zhang XT. A fuzzy multi-criteria decision-making model for trigeneration system. Energy Policy. 2008;36:3823-32.

[144] Kim YS, Lorente S, Bejan A. Distribution of size in steam turbine power plants. International Journal of Energy Research. 2009;33:989-98. 
[145] Edwards W. How to Use Multiattribute Utility Measurement for Social Decisionmaking. Systems, Man and Cybernetics, IEEE Transactions on. 1977;7:326-40.

[146] Edwards W, Barron FH. SMARTS and SMARTER: Improved Simple Methods for Multiattribute Utility Measurement. Organizational Behavior and Human Decision Processes. 1994;60:306-25.

[147] Singh RK, Murty HR, Gupta SK, Dikshit AK. An overview of sustainability assessment methodologies. Ecological Indicators. 2009;9:189-212.

[148] Balkema AJ, Preisig HA, Otterpohl R, Lambert FJD. Indicators for the sustainability assessment of wastewater treatment systems. Urban Water. 2002;4:153-61.

[149] Lundin M, Morrison GM. A life cycle assessment based procedure for development of environmental sustainability indicators for urban water systems. Urban Water. 2002;4:145-52.

[150] Olalla-Tárraga MÁ. A conceptual framework to assess sustainability in urban ecological systems. International Journal of Sustainable Development \& World Ecology. 2006;13:1-15.

[151] Ingunn SM, Bjørn IV. The 2010 LCA of cellulose, ethanol, lignin adn vanillin from Borregaard, Sarpsborg. Ostfold Research, Gamle Beddingvei 2B, N-1671 Kråkerøy2011. p. 1-78.

[152] Borrion AL, McManus MC, Hammond GP. Environmental life cycle assessment of lignocellulosic conversion to ethanol: A review. Renewable and Sustainable Energy Reviews. 2012;16:4638-50.

[153] Thomassen M, Dalgaard R, Heijungs R, Boer I. Attributional and consequential LCA of milk production. International Journal of Life Cycle Assessment. 2008;13:339-49.

[154] Rebitzer G, Ekvall T, Frischknecht R, Hunkeler D, Norris G, Rydberg T, et al. Life cycle assessment: Part 1: Framework, goal and scope definition, inventory analysis, and applications. Environment International. 2004;30:70120.

[155] Ekvall T, Weidema B. System boundaries and input data in consequential life cycle inventory analysis. International Journal of Life Cycle Assessment. 2004;9:161-71.

[156] Cherubini F, Strømman AH, Ulgiati S. Influence of allocation methods on the environmental performance of biorefinery products—A case study. Resources, Conservation and Recycling. 2011;55:1070-7.

[157] Norris G. Integrating life cycle cost analysis and LCA. International Journal of Life Cycle Assessment. 2001;6:118-20.

[158] Bidoki SM, Wittlinger R. Environmental and economical acceptance of polyvinyl chloride (PVC) coating agents. Journal of Cleaner Production. 2010;18:219-25.

[159] Schmidheiny S, Stigson B. Eco-efficiency: creating more value with less impact: World Business Council for Sustainable Development; 2000.

[160] Vogtländer J, Brezet H, Hendriks C. The virtual eco-costs '99 A single LCA-based indicator for sustainability and the eco-costs-value ratio (EVR) model for economic allocation. Int J LCA. 2001;6:157-66.

[161] Kledal PR, Kjeldsen C, Refsgaard K, Söderbaum P. Ecological economics and organic farming. Global Development of Organic Agriculture. 2006:113-33.

[162] TU Delft. (2013). "The Model of the Eco-costs / Value Ratio (EVR)." Retrieved 12/27, 2013, from http://www.ecocostsvalue.com/EVR/model/theory/subject/2-eco-costs.html.

[163] Dalgaard T, Jørgensen U, Kristensen I, Gylling M, Dejgaard J, Dubgaard A, et al. Concepts for a multi-criteria sustainability assessment of a new more biobased economy in rural production landscapes. International Farming Systems Association Conference. Aarhus, Denmark. 2012. p. Workshop 5.1. 9 p.

[164] Fernando AL, Duarte MP, Almeida J, Boléo S, Mendes B. Environmental impact assessment of energy crops cultivation in Europe. Biofuels, Bioproducts and Biorefining. 2010;4:594-604.

[165] Behzadian M, Kazemzadeh RB, Albadvi A, Aghdasi M. PROMETHEE: A comprehensive literature review on methodologies and applications. European Journal of Operational Research. 2010;200:198-215.

[166] Brans J-P, Mareschal B. Promethee Methods. Multiple Criteria Decision Analysis: State of the Art Surveys: Springer New York; 2005. p. 163-86.

[167] Botti L, Peypoch N. Multi-criteria ELECTRE method and destination competitiveness. Tourism Management Perspectives. 2013;6:108-13.

[168] Parajuli R. Looking into the Danish energy system: Lesson to be learned by other communities. Renewable and Sustainable Energy Reviews. 2012;16:2191-9. 
[169] Danish Energy Agency. Annual Energy Statistics. Copenhagen: Danish Energy Agency; 2012.

[170] European Commission. DIRECTIVE 2003/30/EC of the European Parliament and Council- on the promotion of the use of biofuels or other renewable fuels for transport. 2003. p. 1-5.

[171] Lund H, Mathiesen BV. Energy system analysis of 100\% renewable energy systems-The case of Denmark in years 2030 and 2050. Energy. 2009;34:524-31.

[172] Hvelplund F, Lund H, Schaltz E, Pillay JR, Nielsen MP, Felby C, et al. Coherent Energy and Environmental System Analysis. Aalborg University; 2011. p. 1-93.

[173] IDA. The IDA Climate Plan. Copenhagen, Denmark: The Danish Society of Engineers (IDA). 2009. p. 1-253.

[174] Danish Energy Agency. Energy Strategy 2050- from coal, oil and gas to green energy. 1470 Copenhagen K, Denmark: The Danish Ministry of Climate and Energy; 2011. p. 1-66.

[175] Joensen F, Nielsen P, Palis Sørensen M. Biomass to green gasoline and power. Biomass Conv Bioref. 2011;1:8590.

[176] Østergaard PA, Mathiesen BV, Möller B, Lund H. A renewable energy scenario for Aalborg Municipality based on low-temperature geothermal heat, wind power and biomass. Energy. 2010;35:4892-901.

[177] Gylling M, Jørgensen U, Bentsen NS, Kristensen IT, Dalgaard T, Felby C, et al. The +10 Million Tonnes Study : Increasing the sustainable production of biomass for biorefineries. Fødevareøkonomisk Institut, Københavns Universitet; 2013. p. 1-32.

[178] Statistics Denmark. Statistical Year Book 2012. Copenhagen: Statitistics Denmark; 2012. p. 1-542.

[179] FAOSTAT. Agri-environmental statistics. 2013.

[180] DBH Technology A/S. (2011). "Biorefining feed wheat." Retrieved 2013-10-07, 2013, from http://hveiti.dk/en/alternative-soybean-protein.

[181] Bentsen NS, Felby C, Ipsen KH. Energy balance of 2 nd generation bioethanol production in Denmark. DONG Energy; 2006.

[182] Andersen M, Kiel P. Integrated utilisation of green biomass in the green biorefinery. Industrial Crops and Products. 2000;11:129-37.

[183] Jong Ed, van Ree R. Biorefineries: adding value to the sustainable utilisation of biomass. IEA Bioenergy, Task 42; 2009. p. 1-16.

[184] Jørgensen HE. Advanced Biofuels in a Biorefinery Approach. Rolighedsvej 23, Copenhagen, Denmark: UNiversity of Copenhagen; 2012. p. 1-120.

[185] Bio-Value SPIR. (2013). "Value added products from biomass: A strategic platform for innovation and research in biorefining." Retrieved 01/17, 2014, from www.biovalue.dk.

[186] Nguyen TLT, Hermansen JE, Mogensen L. Environmental performance of crop residues as an energy source for electricity production: The case of wheat straw in Denmark. Applied Energy. 2013;104:633-41.

[187] Parajuli R. Life Cycle Assessment of Wheat straw as a fuel input for district heat production: Aalborg University; 2013.

[188] Ahring B, Westermann P. Coproduction of Bioethanol with Other Biofuels. In: Olsson L, editor. Biofuels: Springer Berlin Heidelberg; 2007. p. 289-302. 


\section{$\underline{\text { Figure Captions }}$}

Figure 1: Illustrative flow of biomass to biovalue products in a biorefinery process, modified after the Ref. [75].

Figure 2: Production and export of soybeans from Brazil and gross import of soybean products to Europe and China (Mt DM per year) [179]. 


\section{List of Tables:}

Table 1: Classification of biorefinery, platforms and products

\begin{tabular}{|c|c|c|c|c|}
\hline \multirow{2}{*}{ Types } & \multirow[t]{2}{*}{ Processes } & \multirow{2}{*}{ Feedstocks } & \multicolumn{2}{|c|}{ Products } \\
\hline & & & Energy & Materials \\
\hline $\begin{array}{l}\text { One-platform } \\
\left.\text { ( }_{6} \text { sugars }\right)\end{array}$ & Hydrolysis, fermentation. & Starch crops (Corn). & Bioethanol & Animal feed \\
\hline One-platform ${ }^{1}$ (Oil) & Pressing, transesterification. & Oil crops (Rapeseed). & Biodiesel & $\begin{array}{l}\text { Animal feed } \\
\text { (rape cake), } \\
\text { glycerine }\end{array}$ \\
\hline $\begin{array}{l}\text { One-platform }{ }^{1} \\
\text { (Syngas) }\end{array}$ & $\begin{array}{l}\text { Pre-treatment, gasification, } \\
\text { FT synthesis, alcohol } \\
\text { synthesis. }\end{array}$ & $\begin{array}{l}\text { Lignocellulosic residues } \\
\text { (straw). }\end{array}$ & $\begin{array}{l}\text { Synthetic biofuels } \\
\text { Fischer-Tropsch } \\
\text { (FT-fuels) }\end{array}$ & $\begin{array}{l}\text { Chemicals } \\
\text { (alcohols) }\end{array}$ \\
\hline $\begin{array}{l}\text { Two-platform }{ }^{2} \\
\text { (Sugar and syngas) }\end{array}$ & $\begin{array}{l}\text { Biochemical conversion } \\
\text { (sugar platform), } \\
\text { thermochemical (syngas). }\end{array}$ & $\begin{array}{l}\text { Biomasses (with } 75 \% \\
\text { carbohydrate, } \\
\text { average) }\end{array}$ & $\begin{array}{l}\text { Conditioning gas, } \\
\text { fuels }\end{array}$ & $\begin{array}{l}\text { Chemicals, } \\
\text { polymers }\end{array}$ \\
\hline $\begin{array}{l}\text { Four-platform }{ }^{1} \\
\left(\mathrm{C}_{6} / \mathrm{C}_{5} \text { sugars, lignin, }\right. \\
\text { syngas })\end{array}$ & $\begin{array}{l}\begin{array}{l}\text { Pre-treatment, hydrolysis, } \\
\text { fermentation, gasification, } \\
\text { FT- synthesis. }\end{array}\end{array}$ & $\begin{array}{l}\text { Lignocellulose } \\
\text { (switchgrass). }\end{array}$ & $\begin{array}{l}\text { FT-fuels, } \\
\text { Bioethanol }\end{array}$ & Animal feed \\
\hline
\end{tabular}

${ }^{1}$ Cherubini et al. [35]; ${ }^{2}$ Kamm et al. [190] 
Table 2: Percentage of dry weight composition of the selected biomasses, (based on [30, 44])

\begin{tabular}{|c|c|c|c|}
\hline Feedstock & Cellulose & Hemicellulose & Lignin \\
\hline Bagasse & 41 & 23 & 18 \\
\hline Bamboo & $26-43$ & $15-26$ & $21-31$ \\
\hline Banana Waste & 13 & 15 & 14 \\
\hline Barley straw & 32 & 26 & 23 \\
\hline Coffee pulp & 35 & 46 & 19 \\
\hline Corn cobs & 45 & 35 & 15 \\
\hline Corn stalks & 43 & 24 & 17 \\
\hline Corn stover & 40 & 22 & 18 \\
\hline Grasses & $25-40$ & $25-50$ & $10-30$ \\
\hline Rye grass (early leaf) & 21 & 16 & 3 \\
\hline Switchgrass & 45 & 31 & 12 \\
\hline Hardwood bark & $22-40$ & $20-38$ & $30-55$ \\
\hline Hardwood stem & $40-50$ & $24-40$ & $18-25$ \\
\hline Softwood stem & $45-50$ & $25-35$ & $25-35$ \\
\hline Sorted plant refuse & 60 & 20 & 20 \\
\hline Leaves & $15-20$ & $80-85$ & - \\
\hline Millet husk & 33 & 27 & 14 \\
\hline Wheat straw & 39 & 24 & 16 \\
\hline Rice husk & 31 & 24 & 14 \\
\hline Rice straw & 37 & 23 & 14 \\
\hline Rye grass (seed setting) & 27 & 26 & 7 \\
\hline Rye straw & $33-35$ & $27-30$ & $16-19$ \\
\hline Pine wood & 39 & 24 & 20 \\
\hline Poplar wood & 35 & 17 & 26 \\
\hline Sweet sorghum bagasse & 45 & 25 & 18 \\
\hline Newspaper & $40-55$ & $25-40$ & $18-30$ \\
\hline Waste papers from chemical pulps & $60-70$ & $10-20$ & $5-10$ \\
\hline Nut shells & $25-30$ & $25-30$ & $30-40$ \\
\hline Swine waste & 6 & 28 & - \\
\hline Solid cattle manure & $1.6-4.7$ & 28 & - \\
\hline
\end{tabular}


Table 3: Overview of suitable biorefinery feedstocks with significant related chemical value chains

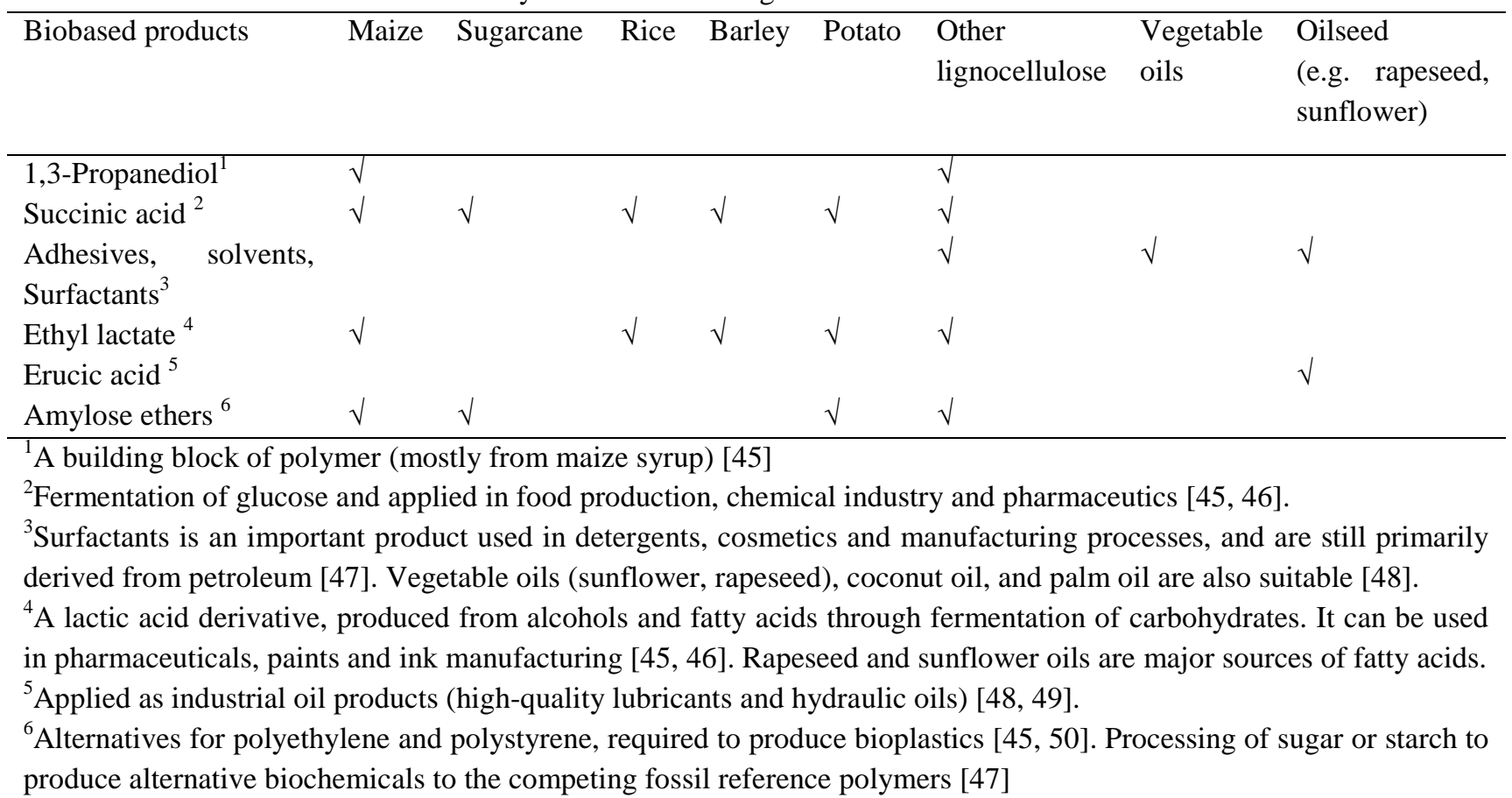


Table 4: Estimated mineral fertilizer (N, P, K) and lime requirements for selected crops grown in temperate climate zones (kg/ha/yr)

\begin{tabular}{llll}
\hline Crops & N & P & K \\
\hline Winter Wheat $^{1}$ & 192 & 22 & 87 \\
Maize $^{2}$ & 228 & 59 & 208 \\
Sorghum $^{2}$ & 130 & 60 & 40 \\
Triticale $^{2}$ & 87 & 76 & 50 \\
Rape (seed) $^{4}$ & 230 & 39 & 347 \\
Sunflower $^{4}$ & 70 & - & - \\
Soybean $^{4}$ & 40 & - & - \\
Potatoes $^{3}$ & 140 & 43 & 140 \\
Sugar beet $^{3}$ & 120 & 21 & 42 \\
Clover/grass $^{3}$ & 64 & 28 & 37 \\
Reed canary grass $^{3}$ & 110 & 19 & 23 \\
Miscanthus (autumn harvest) $^{1,5}$ & $90-107$ & $6-15$ & $45-75$ \\
Willow $^{1,3}$ & $100-120$ & $6-15$ & $45-50$ \\
Barley $^{1}$ & 136 & 22 & 62 \\
Rye grass $^{1}$ & 387 & 42.5 & 239 \\
\hline
\end{tabular}

Data sources: ${ }^{1}$ for Sandy loam soil-Denmark[191]; ${ }^{2}[79] ;{ }^{3}[192] ;{ }^{4}[86] ;{ }^{5}[81]$. 
Table 5: Annual energy input in the cultivation and initial processing of biomass in a temperate climate and estimated production and economically optimal use of synthetic fertilizers and pesticides [81]

\begin{tabular}{lllll}
\hline Particulars & Unit & Corn & Miscanthus & Willow \\
\hline Field preparation & MJ/ha & 933 & 100 & 300 \\
Planting & MJ/ha & 108 & 100 & 100 \\
Fertilizer application & MJ/ha & 72 & 72 & 50 \\
Pesticide application & MJ/ha & 108 & 25 & 25 \\
Harvest+transport & MJ/ha & 1795 & 2190 & 1150 \\
\hline Total & MJ/ha & 3016 & 2487 & 1625 \\
\hline Yield & tDM/ha & 10.12 & 12.7 & 11.18 \\
\hline Energy ratio (output/input) (GJ/GJ) & & 7.2 & 6.9 & 7.3 \\
\hline
\end{tabular}


Table 6: Life cycle impact of fuel generated from different types of biorefinery

\begin{tabular}{|c|c|c|c|c|}
\hline Biorefinery types & $\begin{array}{l}\text { Energy efficiency (Fossil) } \\
\text { (energy input/energy in fuel) }\end{array}$ & $\begin{array}{l}\text { GHG emissions } \\
\text { (g CO} 2 \text {-eq/MJ biofuel) }\end{array}$ & $\begin{array}{l}\mathrm{SO}_{\mathrm{X}} \text { emissions } \\
(\mathrm{g} / \mathrm{MJ})\end{array}$ & $\begin{array}{l}\mathrm{NO}_{\mathrm{x}} \text { emissions } \\
\text { (g/MJ) }\end{array}$ \\
\hline Grain ethanol & $0.33-0.42^{\mathrm{a}}$ & $44-57^{a}$ & 0.066 to $0.081^{b}$ & $0.12-0.25^{b}$ \\
\hline Cellulose ethanol & 0.08 to $0.13^{b, c} ;-0.01$ to $0.15^{d}$ & -5 to $23^{c, d}$ & 0.014 to $0.51^{\mathrm{c}, \mathrm{d}}$ & $0.05-0.65^{\mathrm{d}, \mathrm{e}, \mathrm{f}}$ \\
\hline F-T diesel & $0.05-0.22^{b}$ & -5 to $19^{\mathrm{c}, \mathrm{f}}$ & 0.009 to $0.11^{\mathrm{b}, \mathrm{f}}$ & $0.03-0.1^{\mathrm{b}, \mathrm{f}}$ \\
\hline
\end{tabular}

Data sources: ${ }^{\mathrm{a}}[194] ;{ }^{\mathrm{b}}[113,195] ;{ }^{\mathrm{c}}[196] ;{ }^{\mathrm{d}}[197] ;{ }^{\mathrm{e}}[198] ;{ }^{\mathrm{f}}[193]$ 
Table 7: Sustainability assessment tools and possible indicators essential for the assessment

\begin{tabular}{|c|c|c|}
\hline Tools & Measures used & References used \\
\hline \multicolumn{3}{|l|}{ Monetary tools } \\
\hline $\begin{array}{l}\text { Economic cost basis (e.g.): } \\
\text { - Investment analysis } \\
\text { - Revenue to feedstock ratio } \\
\text { - Revenue to main product ratio }\end{array}$ & $\begin{array}{ll}\text { - } & \text { Cost-Benefit Analysis } \\
\text { - } & \text { Net present value } \\
\text { - } & \text { Annualized cost } \\
\text { - } & \text { Payback period } \\
& \text { Valuation of material choice or } \\
& \text { production system }\end{array}$ & Economics: $[7,199-206]$ \\
\hline $\begin{array}{l}\text { Eco-cost (e.g.) } \\
\text { - Pollution prevention eco-cost } \\
\text { - Eco-cost of energy } \\
\text { - Eco-cost of material depletion }\end{array}$ & $\begin{array}{l}\text { - Changes in the eco-cost due to } \\
\text { alternative choices and production } \\
\text { system }\end{array}$ & $\begin{array}{l}\text { Eco-cost and EVR: }[118,161] \\
\text { Indicators of material depletion: } \\
{[119]}\end{array}$ \\
\hline $\begin{array}{l}\text { Bio-physical tools } \\
\text { - Material flow analysis } \\
\text { - Product substitution effects }\end{array}$ & $\begin{array}{l}\text { - Mass balance, energy balance, exergy } \\
\text { analysis } \\
\text { Economic and environmental } \\
\text { differences between choices/ } \\
\text { alternative production chains }\end{array}$ & $\begin{array}{l}\text { Technical: }[120,121,199,200] \\
\text { Environmental: }[83,120-124, \\
199]\end{array}$ \\
\hline $\begin{array}{l}\text { Indicator tools } \\
\text { Resource indicators (e.g.) } \\
\text { - Fuel consumption } \\
\text { - Material extraction } \\
\text { - Fuel depletion } \\
\text { Environmental indicators (e.g.) } \\
\text { - Land-use (direct/indirect) } \\
\text { - Environmental impact categories } \\
\text { (as used in LCA studies). } \\
\text { Social indicators (e.g.) } \\
\text { - Social acceptance } \\
\text { - Waste disposal } \\
\text { - Participation } \\
\text { - Health impacts } \\
\text { - Aesthetic impacts } \\
\text { - Employment }\end{array}$ & $\begin{array}{l}\text { - Weighing of the indicators based on } \\
\text { the region/country/local sustainability } \\
\text { goal settings and ecological } \\
\text { management initiatives. } \\
\text { - } \quad \text { Quantification of impacts (LCA) } \\
\text { - } \quad \text { Monetization of impacts (LCCA) } \\
\text { Aggregating the criteria (Multi- } \\
\text { Criteria Assessment) }\end{array}$ & $\begin{array}{l}\text { LCA for environment impact } \\
\text { characterization: }[83,122-124, \\
207]\end{array}$ \\
\hline
\end{tabular}


Table 8: Five major principles (elaborated from Wang et al. [139]) in relation to sustainability assessment of biorefinery processes and examples on the related criteria for decision-making

\begin{tabular}{ll}
\hline Principles & Criteria/dimensions of the assessment \\
\hline i) The Systems Principle & Technical and process design of biorefinery: processing efficiency, mass flow, \\
& aims for the potential substitution/displacement of fossil-fuel-based products by \\
& biobased products. \\
ii) The Consistency Principle & In coherence with the national/regional/global strategies on sustainable \\
& development, e.g. the EU-biofuel [9] and bioeconomy strategy [51]. Resource \\
& management and diversification of use in relation to sustainability goals. \\
iii) The Independency Principle & Comparative economic and environmental performance of the biomass \\
& conversion in biorefinery with respect to alternatives (e.g. combustion, \\
& thermochemical, gasification etc.). Socio-economic and environmental \\
& differences with respect to biorefinery pathways but differing the feedstocks \\
& supply scenarios, and differing products scenarios (extent of processing). \\
& Qualitative and quantitative analysis of the process and product system. \\
iv) The Measurability Principle & Quantification of sustainability assessment criteria/indicators (e.g. GWP per kg \\
& of bioethanol, annualized cost of producing 1 kg of ethanol, animal feed etc., \\
& potential employment generation per kg of ethanol etc.). \\
& In relation to the principle (iii) as stated above, ecological and socio-economic \\
& aspects of utilizing various inputs to produce marketable products in a biorefinery \\
process.
\end{tabular}

Table 9: Schematic matrix of evaluation process

\begin{tabular}{lll}
\hline Evaluation schemes (e.g.) & $\begin{array}{c}\text { Weight } \\
\text { indicators }\end{array}$ & $\begin{array}{l}\text { Quantification of impact e.g. per tDM } \\
\end{array}$ \\
\hline Criteria /indicators: Environmental (env.) & \\
\hline GWP & \\
\hline Non-renewable energy use & \\
\hline Acidification potential & \\
\hline Eutrophication potential & \\
\hline Material extraction & \\
\hline '. $n$ '.
\end{tabular}

\section{Criteria /indicators: Economics}

e.g. Cost benefit ratio

...

'n'. 




Figure 1: Illustrative flow of biomass to biovalue products in a biorefinery process, modified after the Ref. [75]. 


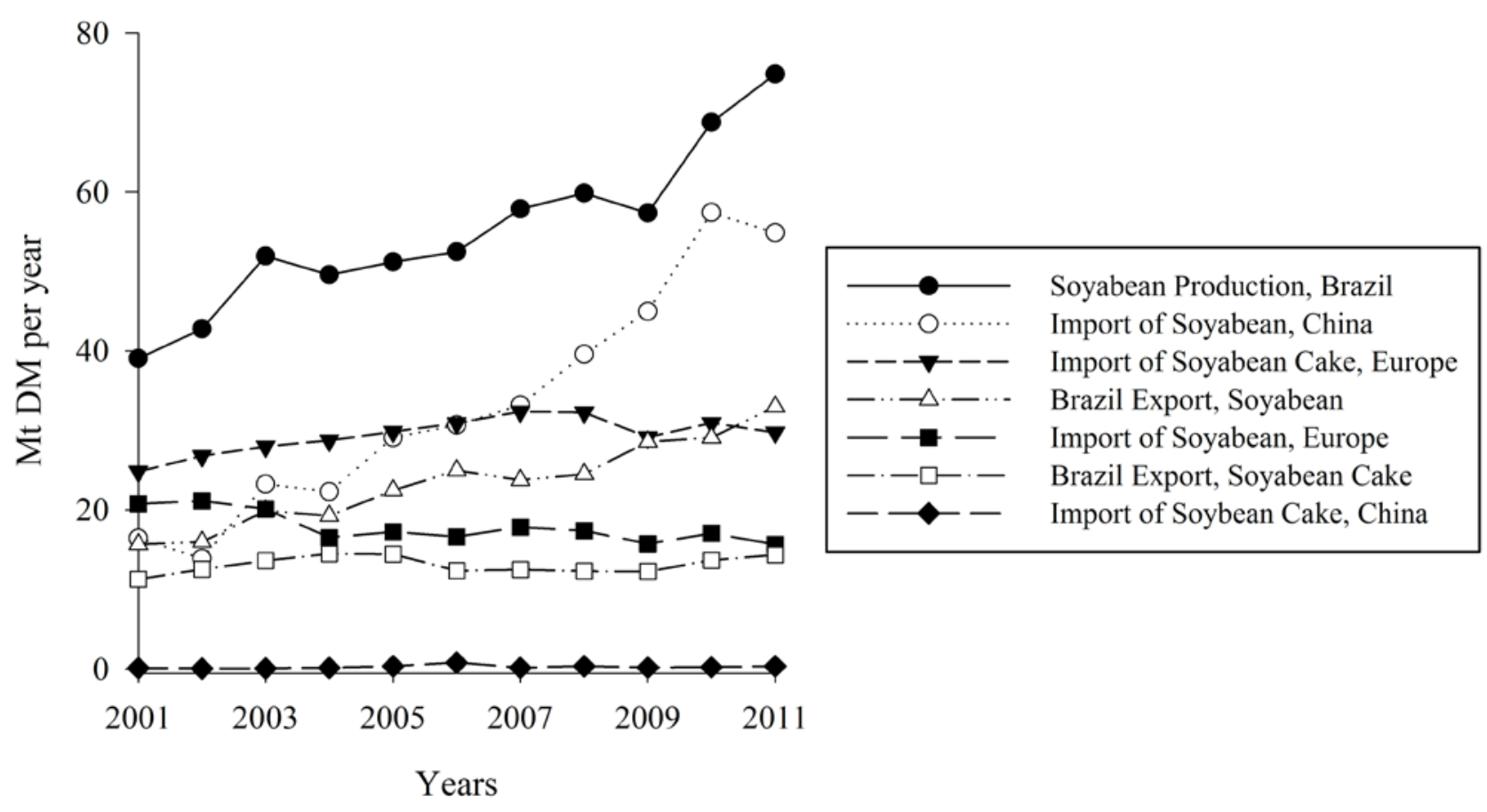

Figure 2: Production and export of soybeans from Brazil and gross import of soybean products to Europe and China (Mt DM per year) [179]. 